\title{
Parametric analysis of lava dome-collapse events and pyroclastic deposits at Shiveluch volcano, Kamchatka, using visible and infrared satellite data
}

\author{
Janine B. Krippner ${ }^{\text {a,* }}$, Alexander B. Belousov ${ }^{\text {b }}$, Marina G. Belousova ${ }^{\text {b }}$, Michael S. Ramsey ${ }^{\text {c }}$ \\ a Department of Physical Science, Concord University, 1000 Vermillion Street, Athens, WV 24712, USA \\ ${ }^{\mathrm{b}}$ Institute of Volcanology and Seismology, Russia \\ c Department of Geology and Environmental Science, University of Pittsburgh, USA
}

\section{A R T I C L E I N F O}

\section{Article history:}

Received 1 August 2017

Received in revised form 30 January 2018

Accepted 31 January 2018

Available online 10 February 2018

\section{Keywords:}

Shiveluch

Lava dome-collapse

Block-and-ash flow

Pyroclastic density current

ASTER

\begin{abstract}
A B S T R A C T
For the years 2001 to 2013 of the ongoing eruption of Shiveluch volcano, a combination of different satellite remote sensing data are used to investigate the dome-collapse events and the resulting pyroclastic deposits. Shiveluch volcano in Kamchatka, Russia, is one of the world's most active dome-building volcanoes, which has produced some of the largest known historical block-and-ash flows (BAFs). Globally, quantitative data for deposits resulting from such large and long-lived dome-forming eruptions, especially like those at Shiveluch, are scarce. We use Advanced Spaceborne Thermal Emission and Reflection Radiometer (ASTER) thermal infrared (TIR), shortwave infrared (SWIR), and visible-near infrared (VNIR) data to analyze the dome-collapse scars and BAF deposits that were formed during eruptions and collapse events in 2001, 2004, 2005, 2007, 2009, 2010 , and two events in 2013. These events produced flows with runout distances of as far as $19 \mathrm{~km}$ from the dome, and with aerial extents of as much as $22.3 \mathrm{~km}^{2}$. Over the 12 years of this period of investigation, there is no trend in deposit area or runout distances of the flows through time. However, two potentially predictive features are apparent in our data set: 1 ) the largest dome-collapse events occurred when the dome exceeded a relative height (from dome base to top) of $500 \mathrm{~m} ; 2$ ) collapses were preceded by thermal anomalies in six of the cases in which ASTER data were available, although the areal extent of these precursory thermal areas did not generally match the size of the collapse events as indicated by scar area (volumes are available for three collapse events). Linking the deposit distribution to the area, location, and temperature profiles of the dome-collapse scars provides a basis for determining similar future hazards at Shiveluch and at other dome-forming volcanoes. Because of these factors, we suggest that volcanic hazard analysis and mitigation at volcanoes with similar BAF emplacement behavior may be improved with detailed, synoptic studies, especially when it is possible to access and interpret appropriate remote sensing data in near-real time.
\end{abstract}

(C) 2018 Elsevier B.V. All rights reserved.

\section{Introduction}

Volcanic lava domes are solidified or semi-solidified highly viscous masses of extruded lava at a volcano. The partial collapse of growing lava domes can produce block-and-ash flows (BAFs), often with minimal warning (Calder et al., 2015). The prolonged eruption duration and the difficult nature of forecasting dome-collapse events can result in fatalities, social disruptions, or permanent evacuations of surrounding populations either because of the BAF or related pyroclastic surges (Charbonnier et al., 2013 and references therein). Past well-known examples of prolonged eruption durations include the eruptions of Mt.

\footnotetext{
* Corresponding author at: Concord University, 1000 Vermillion Street, Athens, WV 24712, USA.

E-mail address: jkrippner@concord.edu (J.B. Krippner).
}

Pelée (Fisher and Heiken, 1982), Unzen volcano (Miyabuchi, 1999), Soufrière Hills volcano (Cole et al., 2002), and Merapi and Sinabung volcanoes (Surono et al., 2012; Gunawan et al., 2017). At Sinabung volcano in Indonesia, the current eruption (since 2013) has damaged or destroyed 10 villages and two hamlets, and has displaced almost 10,000 people (Yulianto et al., 2016; Andreastuti et al., 2017). Shiveluch is located in a remote area of northern Kamchatka (Klyuchi, the nearest town is $50 \mathrm{~km}$ from the dome). Shiveluch was selected for this study due to the ongoing dome-forming eruption (at the time of publication) that has produced BAF deposits that range widely in area and distribution, and consequently provide new insights into this type of eruption. In addition, unlike the case at Montserrat (Cole et al., 2002; Sparks et al., 2002; Herd et al., 2005; Wadge et al., 2014), the BAF deposits on Shiveluch are entirely on land and consequently, well exposed over their full extents. Eight dome-collapse events and the resulting BAF 
deposits were selected for this study, for which visible-near infrared (VNIR), shortwave infrared (SWIR), and thermal infrared (TIR) data from the Advanced Spaceborne Thermal Emission and Reflection Radiometer (ASTER) sensor are available before and after the collapse events. Ranges in the BAF deposit areas and runout distances are compared to activity at the dome and the conditions that result in these distributions are assessed.

The relationships between the pre-collapse areas of elevated thermal output and the area and location of the subsequent collapse events are investigated in order to assess the value of TIR data for identifying pre-dome-collapse indicators at Shiveluch. For this study, we characterize the dome-collapse scars (the area excavated during a collapse event) using planimetric areal extent and the location of collapse areas on the dome. The deposits are then characterized using spatial distribution (including runout distance), maximum width, and dome-collapse volume where available.

\subsection{Study area}

Shiveluch volcano (also spelled Sheveluch) is located in the northern part of the Central Depression of Kamchatka, where the KurilKamchatka and Aleutian subduction zones intersect, and is the northern-most active volcano in Kamchatka. The volcano is divided into Old Shiveluch (3335 m), a Pleistocene-age edifice that was partially destroyed by a $>10 \mathrm{~km}^{3}$ debris avalanche with an age of $10 \mathrm{ka}$, and Young Shiveluch (Molodoy in Russian, $2763 \mathrm{~m}$ ) that subsequently formed within this collapse scar, and is where modern volcanism occurs (Belousov et al., 1999). Shiveluch has undergone at least seven large edifice collapse events, dated at approximately 10,000, 5700, 3700, 2600, $1600,600 \mathrm{BP}$, and $1964 \mathrm{CE}$, with the high frequency of failure events attributed to the high supply rate of viscous andesite magma (Belousov et al., 1999). Such high magma supply rates also result in rapid reconstruction of the edifice following these collapse events.

The cone of Young Shiveluch is composed of overlapping domes, short lava flows up to $100 \mathrm{~m}$ thick, and volcanic breccias, and a lowangle volcaniclastic fan extends to $>20 \mathrm{~km}$ to the south (Dirksen et al., 2006). Young Shiveluch has experienced six major eruptive periods, largely consisting of dome formation and collapse (Belousov, 1995 and references therein). The currently-active dome of Young Shiveluch is situated within the most recently-formed 1964 CE 1750-m-wide south-facing collapse crater (Fig. 1), and has formed through several cycles of growth and partial collapse during the currently-16-year-long eruption. The northern part of the dome has grown against the 1964 collapse scarp and a talus cone surrounds the southern portion of the dome and extends down to two large ( $1.5 \mathrm{~km}$-wide) slide blocks that formed during the 1964 collapse (Belousov et al., 1999; Fig. 1b). These blocks direct the flows to the southeast or southwest depending on the collapse location on the dome. After being directed SE and/or SW, the majority of the flows then travel along the eastern and western edges of a 1964 hummocky debris avalanche deposit fan.

\subsection{Terminology}

Here, the term 'block-and-ash flow' describes the motion of a mass of rock fragments and hot gas released during dome-collapse (Fig. 2) (Bursik et al., 2005). The BAFs at Shiveluch are produced mainly by Merapi-type events, in which dome-collapses are the result of gravitational failure (Bardintzeff, 1948). The term 'pyroclastic density current' (PDC) is used when the initiation mechanism (solely dome collapse or also including eruption column collapse) is unclear.

\section{Summary of the recent eruption history of Shiveluch}

Volcanic activity prior to 2001 has been described by Belousov (1995), Gorelchik et al. (1997), Fedotov et al. (2004), Zharinov and Demyanchuk (2008), Gorbach and Portnyagin (2011), and Zharinov and Demyanchuk (2013), and volcano activity reports are available online (KVER/VONA Weekly Release, n.d). Three main recent domeforming cycles have occurred in 1980-1981, 1993-1995, and 2001onwards (Fedotov et al., 2004). Dome growth rates during the current 2001-onwards cycle have ranged from 150,000 to $700,000 \mathrm{~m}^{3} /$ day (approximately 2 to $8 \mathrm{~m}^{3} / \mathrm{s}$ ) (Table 1 ). Since 1980, the dome height has been increasing with intermittent reductions in height due to collapse events (Fig. 3).

The style of dome growth has largely been exogenous with intermittent periods of endogenous growth, which has constructed a dome consisting of overlapping lobes (Shevchenko et al., 2015). The viscous, blocky andesite lavas have formed radial, bilateral symmetrical, and irregularly spreading lobes or petals throughout the eruption period (Dirksen et al., 2006; Ramsey et al., 2012; Shevchenko et al., 2015).

Shiveluch also produces pyroclastic surges, associated lahars, and small to regionally extensive ash plumes (Fedotov et al., 2001; Zharinov and Demyanchuk, 2008; Zharinov and Demyanchuk, 2013; Shevchenko and Svirid, 2014). Explosions and partial collapses commonly excavate explosion pits and collapse chutes or scars (Shevchenko et al., 2015). Shiveluch dome-collapse events are
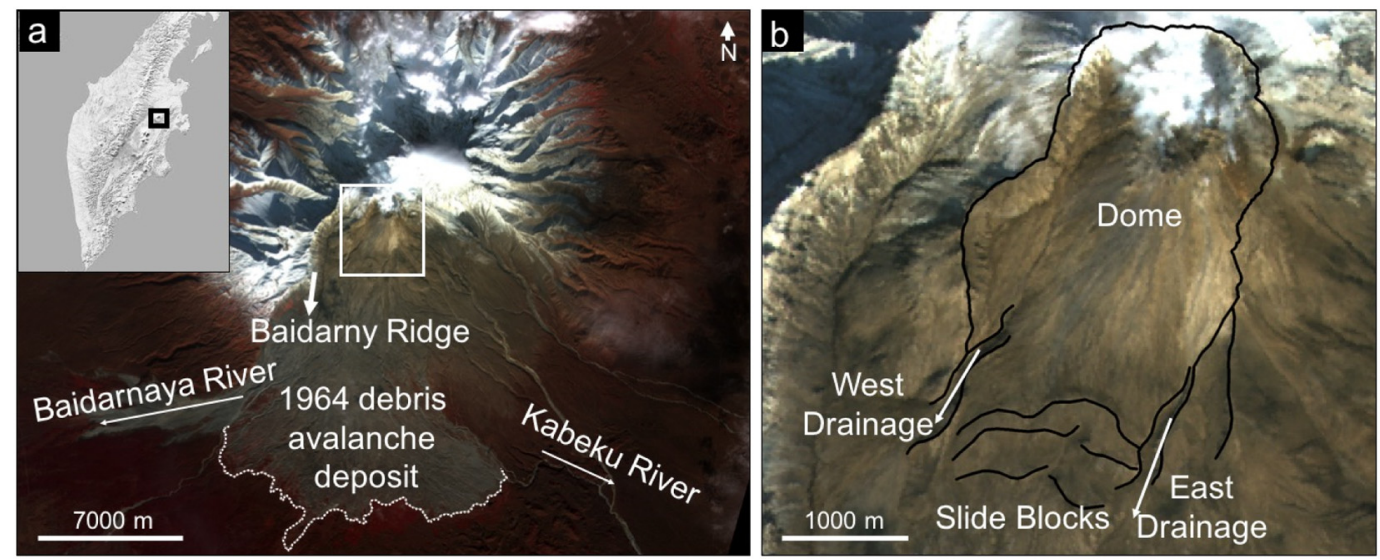

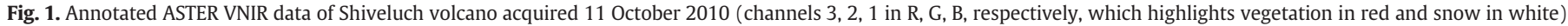

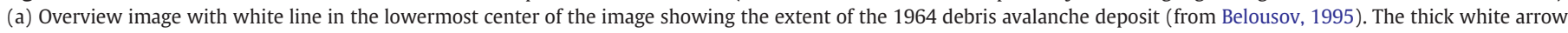

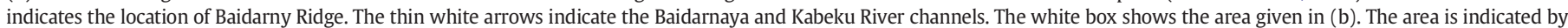

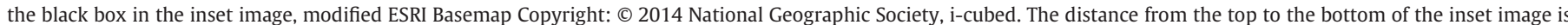

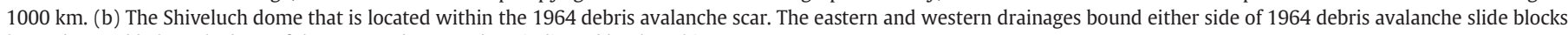
located at, and below, the base of the current dome, and are indicated by the white arrows. 


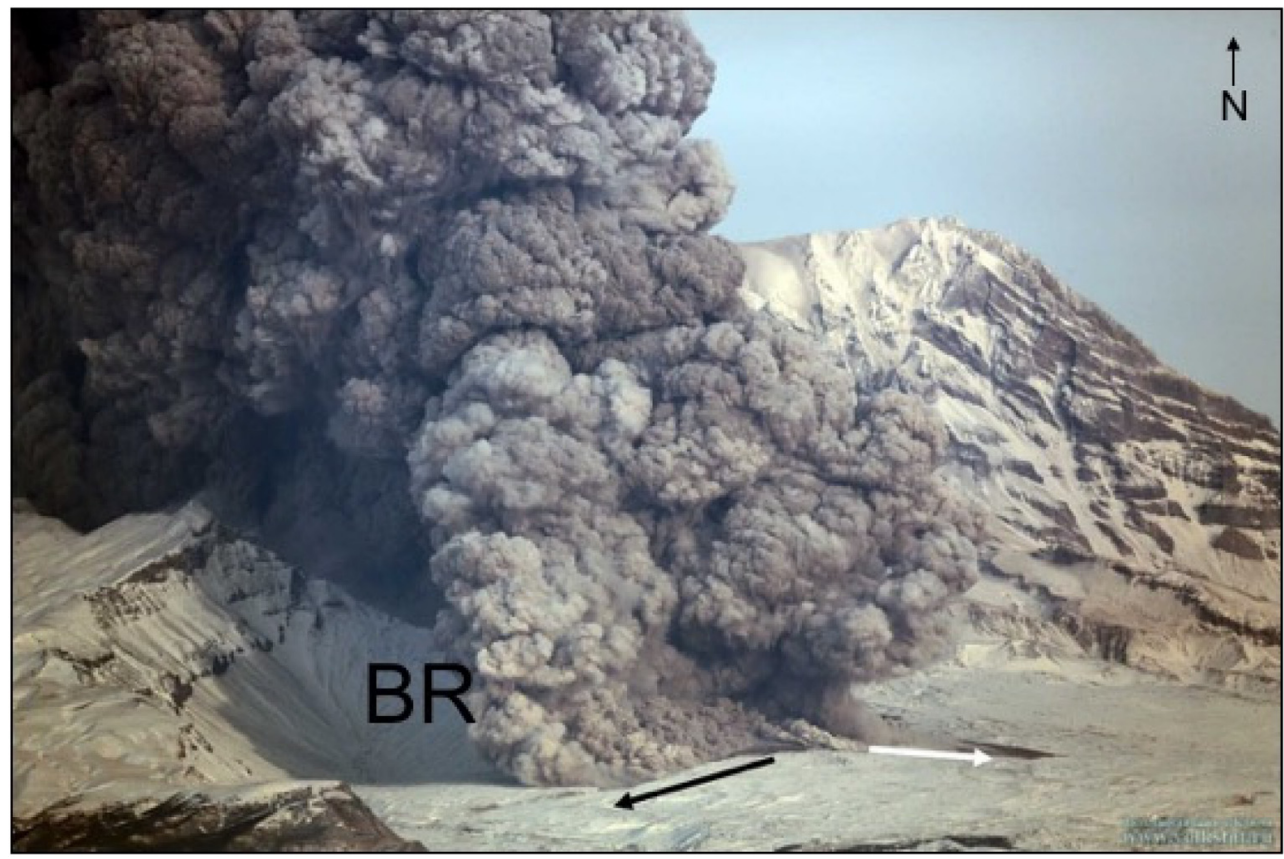

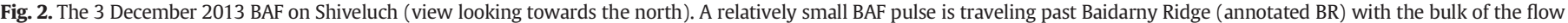
directed towards the west (black arrow) and a smaller portion of flow freshly deposited to the east (white arrow). Photograph courtesy of Yuri Demyanchuk.

hazardous to aircraft, as associated ash plumes can reach flight levels and extend hundreds of kilometers from the volcano.

Zharinov and Demyanchuk (2008, 2013) give detailed accounts of lava dome dimensions (heights, widths, volumes, and profiles), viscous lava extrusion, gas emissions, and seismicity (volcanic tremor, tectonic earthquakes) from 2001 to 2012 . The $>0.63 \mathrm{~km}^{3}$ dome (2012 volume in Shevchenko et al., 2015) began its current cycle of growth in April 2001 after a period of quiescence that followed the 1993-1995 activity (Gorbach, 2006; Shevchenko and Svirid, 2014). The $\mathrm{SiO}_{2}$ content of the lavas has increased over time, from 58.5\% in 1964 and about $61 \%$ in 2001 to as much as about 63\% in 2007-2008 and 2013 (Table 2). The dome is composed of hornblende-plagioclase andesite to low-silica dacite (Gorbach et al., 2016). During the 2001-2013 period, Shiveluch has undergone two major cycles of dome growth including multiple collapse events, with the largest collapse events occurring when the maximum height of the dome stabilized for an extended period at approximately 520 and $560 \mathrm{~m}$. The eight collapse events within the current eruption period have been chosen for more detailed analysis based on the large deposit size (large enough to be visible in satellite images) and the availability of satellite data around the collapse date, before subsequent flows bury the deposit. The eight collapse event details, where available, are shown in Table 3.

Table 1

The available Shiveluch volcano dome growth rates from Shevchenko et al., 2015 and references therein.

\begin{tabular}{ll}
\hline Date range & Rate $\left(\mathrm{m}^{3} /\right.$ day $)$ \\
\hline 23 August to 22 October 1980 & 186,000 \\
4 April to 24 August 1993 & 810,000 \\
1993 to 1995 & 280,000 \\
29 April 2001 to 16 May 2001 & 700,000 \\
16 May 2001 to 7 October 2003 & 320,000 \\
7 October 2003 to 21 August 2005 & $>175,000$ \\
21 August 2005 to 22 November 2010 & $\geq 220,000$ \\
22 November 2010 to 12 July 2012 & 150,000 \\
\hline
\end{tabular}

\section{Methodology}

The eight deposits were chosen for their large size to minimize the error in calculating the areas and travel distances using the $15 \mathrm{~m}$ pixel resolution of the ASTER VNIR data. The dome collapse scars (the area of collapse on the dome) and the BAF deposits are identified visually using VNIR data along with identifying areas of increased temperature in TIR data. The visual identification was done by comparing before and after scenes and identifying the contrast in color between the deposit and the background (the earlier deposits or snow cover) and the clear scar boundaries are visible on the dome due to the steep scarp walls cutting into the dome carapace. The visual interpretations were frequently compared with ASTER TIR data because the deposits and surfaces within the scars produce higher temperatures than the surrounding areas. The higher temperatures are due to the hot inner dome material that is exposed when a portion of the dome collapses, and then subsequently forms the hot deposits. This contrast is increased during the winter months when background surface temperatures on the volcano can drop below $-20^{\circ} \mathrm{C}$. The area of the deposits and the dome collapse scars were interpreted manually in ArcMap, using both VNIR and TIR data, with $15 \mathrm{~m}$ and $90 \mathrm{~m}$ pixel resolution, respectively. The 2005 deposit was interpreted using high resolution panchromatic WorldView-02 data with a pixel resolution of $0.46 \mathrm{~m}^{2}$, giving a more accurate area. The 2010 and 2013 deposits were interpreted using high resolution QuickBird-02 data with a pixel resolution of $0.65 \mathrm{~m}^{2}$. Based on the spatial resolution of the data and incorporating human error with manual tracing, conservative error estimates are $\pm 250 \mathrm{~m}^{2}$ for the areas calculated using ASTER, and $\pm 30 \mathrm{~m}^{2}$ and $50 \mathrm{~m}^{2}$ for the WorldView-02 and QuickBird-02 data, respectively. The June 2009 deposit has a higher level of uncertainty as the deposit was partially covered in snow by the time a cloud-free scene was acquired, so this deposit boundary was largely identified using ASTER TIR data.

\subsection{ASTER data}

Several studies have used TIR data to study active volcanic domes, for example: Mount St. Helens in 2004-05 (Vaughan et al., 2005; 


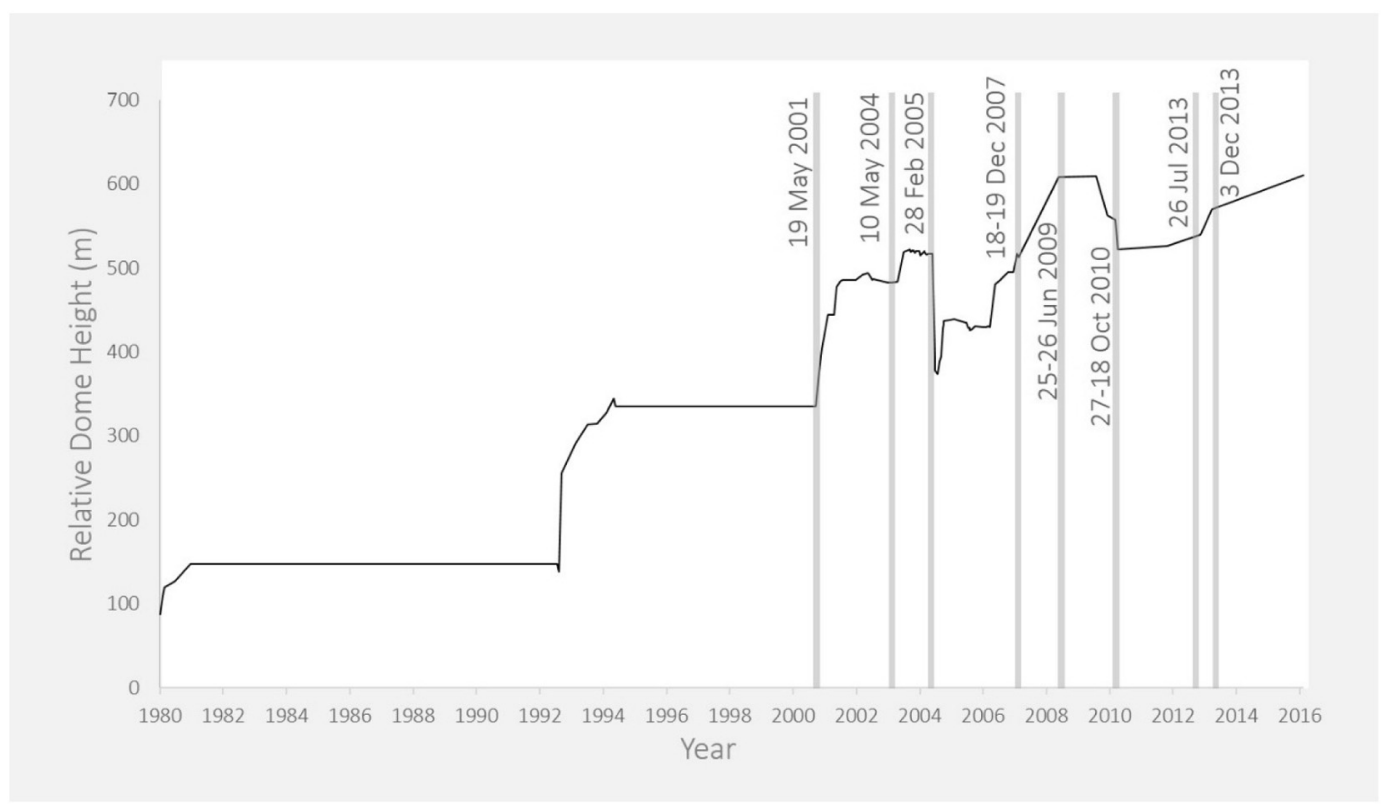

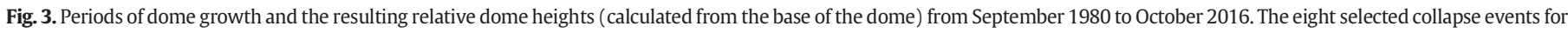

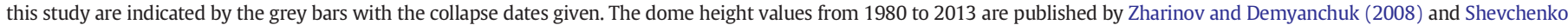
et al. (2015), and the 2013-2016 dome heights are estimated during this study from photographs taken by Yuri Demyanchuk.

Schneider et al., 2008), Chaitén (Bernstein et al., 2013), Bezymianny (Ramsey and Dehn, 2004; Carter et al., 2007), and Shiveluch (Ramsey et al., 2012). These studies used data acquired from ground-based cameras, airborne sensors, and satellite instruments to determine domegrowth styles, surface structures/textures, and to detect episodes of new activity.

Archival ASTER data scenes were selected based on minimal cloud cover (cloud absent over the dome or the deposit of interest) and acquisition dates as close to the event dates as possible. The selected data spanned the times preceding and following each event (Table 4). ASTER data are acquired by three different subsystems: $15 \mathrm{~m}$ resolution 0.5-1.0 $\mu \mathrm{m}$ VNIR, $30 \mathrm{~m}$ resolution 1.0-2.5 $\mu \mathrm{m}$ SWIR, and $90 \mathrm{~m}$ resolution $8-12 \mu \mathrm{m}$ TIR, and all three of these are used in this study. All scenes were checked for geolocation accuracy to ensure spatial consistency by checking several designated pixels that have not undergone change through time (i.e. areas outside of the changing dome and deposit fan).

Table 2

Summary of the published Shiveluch eruptive product compositions over time.

\begin{tabular}{|c|c|c|}
\hline Year & $\mathrm{wt} \% \mathrm{SiO}_{2}$ & Reference \\
\hline $\begin{array}{l}1964 \\
\text { eruption } \\
\text { avg. }\end{array}$ & 58.5 & $\begin{array}{l}\text { Bindeman et al., 2004, Kepezhinskas et al., 1997, } \\
\text { Hochstaedter et al., 1996, Dirksen et al., } 2006\end{array}$ \\
\hline $\begin{array}{l}1980 \\
\text { eruption } \\
\text { avg. }\end{array}$ & 60.3 & Pineau et al., 1999, Dirksen et al., 2006 \\
\hline $\begin{array}{l}1993 \\
\text { eruption } \\
\text { avg. }\end{array}$ & 61.1 & Tolstykh et al., 2000, Dirksen et al., 2006 \\
\hline $\begin{array}{l}1995 \\
\text { eruption } \\
\text { avg. }\end{array}$ & 60.6 & Tolstykh et al., 2000, Dirksen et al., 2007 \\
\hline 2001 & $61.3-61.8$ & Dirksen et al., 2006; Gorbach et al., 2016 \\
\hline 2002 & 62.4 & Dirksen et al., 2006 \\
\hline 2004 & $62.7-64.0$ & Gorbach, 2006, Gorbach et al., 2016 \\
\hline 2005 & $61.2-62.7$ & Gorbach et al., 2016 \\
\hline 2007-08 & $60.6-63.5$ & Gorbach et al., 2016 \\
\hline 2013 & $60.8-63.0$ & Gorbach et al., 2016 \\
\hline
\end{tabular}

TIR data were predominantly used to detect elevated temperatures, and higher temperatures were detected using SWIR data, however the SWIR subsystem failed in 2008 so SWIR data are not available for events that occurred after 2008. Night time data is preferable as it eliminates the additional input of solar radiation. The ASTER TIR night time data are downloaded as AST_09 T surface radiance products, which have a saturation temperature of approximately $97{ }^{\circ} \mathrm{C}$ (Urai et al., 1999). This product is atmospherically corrected using the standard Moderate Resolution Transmittance (MODTRAN) radiative transfer correction model, which accounts for temperature, water vapor, elevation, ozone, and aerosols to estimate atmospheric scattering, emission, and downwelling radiance (NASA LP DAAC, 2001; Tonooka and Palluconi, 2005). The atsurface radiance data are finally separated into emissivity and pixelintegrated brightness temperature using the standard normalization emissivity approach within ENVI software, and are accurate to within $2{ }^{\circ} \mathrm{C}$ (Realmuto, 1990; Gillespie et al., 1998, Gustafson et al., 2006). The standard ENVI Calculate Emittance Parameters were used, except that the Assumed Emissivity Value was changed to 0.98 for each TIR scene analysis. SWIR nighttime data are processed slightly differently using the assumption that any detected radiance is due solely to high temperature surfaces. Pixel integrated temperature is derived from band $4(1.6-1.7 \mu \mathrm{m})$ using the Plank Equation and assuming an emissivity of 1 . The detection threshold for temperatures in this SWIR band ranges from 283 to $467{ }^{\circ} \mathrm{C}$ (low gain) and $250-410{ }^{\circ} \mathrm{C}$ (high gain), depending on which of these gain settings was used during data acquisition. The temperatures reported are the minimum temperatures for a given pixel, as they represent a mixed-temperature surface that could contain both hotter, and cooler areas.

For the analysis of surface temperatures on the dome it was sometimes necessary to use day time TIR data when the dome was not visible in night time data due to cloud cover. Daytime TIR and SWIR scenes were collected as close to the eruption date as possible in addition to the closest consecutive day and night pair (one day time and one night time scene collected within a 24-hour period). These scenes are initially processed using the same method as the nighttime data, but require additional removal of solar radiance. The solar radiance input was calculated under the assumption that the amount of solar radiance for the scene of interest would be the same as the average temperature 


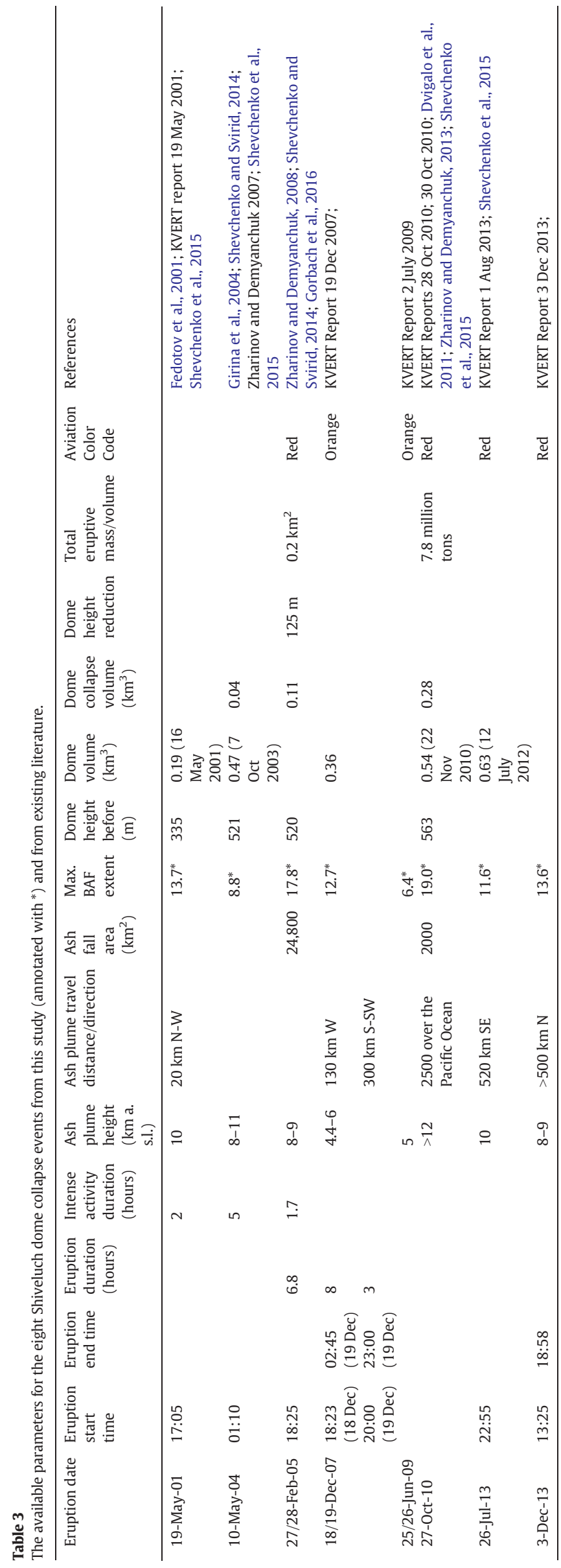

background difference between the consecutive day-night pair, in the same location (excluding the pixels showing elevated temperatures due to dome activity). The average background temperature difference between the two day-night pair scenes was calculated and removed from the daytime data using the bandmath function in ENVI.

\subsection{Dome collapse and deposit distribution analysis}

Eight BAF deposits from 2001 to 2013 are analyzed using the combination of the ASTER VNIR and TIR data described above. Using ASTER VNIR data, the runout lengths (the straight-line horizontal length) of the BAF deposits were manually measured in ESRI ArcMap. The material that is the source for the BAFs comes from different areas within the steep, $\sim 1550 \times 3500 \mathrm{~m}$ dome and across distances as much as $3.5 \mathrm{~km}$, therefore, there is no singular point of origin for the entire material that spans a single deposit. Consequently, by using both the top and base of the collapse scar on the dome that resulted from each event, the resulting range in run-out distances represents the maximum and minimum flow lengths and this range is given in Table 5. However, throughout this report the maximum runout distance is given as the length measured from the top of the collapse scar to the distal end of the deposit for simplicity. The locations of the features within the BAF deposits are given in kilometers from the uppermost point, or headwall scarp, of the dome collapse area, and are, therefore, maximum lengths. The runout length is also calculated from the dome base where the flows exit the erosional channels (Fig. 1b) for a comparative length from a consistent location, given in Table 5 , because the dome scars are not visible at later dates after subsequent dome growth. The maximum temperatures of the deposits and the area of the precursory thermal anomalies are calculated using ASTER TIR data, and SWIR data when the scenes are available, and the number of days that lapse between the collapse dates and the data acquisition are given in Table 6. The longer the time between the collapse event and the data acquisition allows more time for the dome rock to cool, and the temperatures are considered to be minimum temperatures for the surface dome rock. The precursory thermal anomalies on the dome surface are interpreted by analyzing pre-collapse images, calculating the surface temperatures, creating temperature contours of the areas of elevated temperature, then overlaying the contours onto the VNIR images that show the dome collapse area. Dome-collapse dimensions (e.g., planimetric area and length) are calculated using a combination of ASTER TIR and VNIR data. The TIR and VNIR scene dates and the number of days that the scene was acquired after the event date are given in Table 6. The TIR scenes acquired closer to the event date give more accurate temperatures for the exposed dome rock, but elevated temperatures are present for long periods after the collapse occurs.

\section{Results}

Careful examination of the ASTER VNIR and TIR data, combined with field validation, give a timeline of the recent dome collapse and BAF depositional history of Shiveluch.

\subsection{May 2001}

This eruption produced a BAF originating from the northwestern side of the dome, forming a $0.33 \mathrm{~km}^{2}$ collapse scar equant in shape but with irregular edges (Fig. 4a-b). Within the dome scar, a maximum measured pixel-integrated brightness temperature of $445^{\circ} \mathrm{C}$ was registered in a single $30 \mathrm{~m}^{2}$ SWIR pixel in the data that was acquired the same day as the event. However, temperatures likely exceeded $445^{\circ} \mathrm{C}$ at the top of the collapse scar where a steam plume obscured the dome rock in the SWIR image. This is the hottest temperature detected out of all of the eight dome-collapse scars. The temperatures of the dome surface prior to the collapse register at around $10{ }^{\circ} \mathrm{C}$, giving a 
Table 4

The ASTER VNIR, SWIR, and TIR data scenes that were used in this study with the product information given.

\begin{tabular}{|c|c|c|c|c|}
\hline Acquisition & Product ID & Product Name & Day/Night & Scene ID \\
\hline 19-May-01 & AST_09T & Surface Radiance TIR & Night & SC:AST_L1A.003:2003153825 \\
\hline 19-May-01 & AST L1B & Surface Radiance SWIR & Night & SC:AST_L1A.003:2003153825 \\
\hline 14-Feb-02 & AST_07XT & Surface Reflectance VNIR & Day & SC:AST_L1A.003:2006045159 \\
\hline 11-May-04 & AST_09T & Surface Radiance TIR & Night & SC:AST_L1A.003:2023494312 \\
\hline 4-Jun-04 & AST_07XT & Surface Reflectance VNIR & Day & SC:AST_L1A.003:2024291013 \\
\hline 4-Jun-04 & L1B & Surface Radiance SWIR & Night & SC:AST_L1A.003:2024291013 \\
\hline 23-Feb-05 & L1B & Surface Radiance SWIR & Night & SC:AST_L1A.003:2030456561 \\
\hline 12-Mar-05 & AST_07XT & Surface Reflectance VNIR & Day & SC:AST_L1A.003:2028072070 \\
\hline 12-Mar-05 & AST_09T & Surface Radiance TIR & Day & SC:AST_L1A.003:2028072070 \\
\hline 29-Mar-05 & L1B & Surface Radiance SWIR & Night & SC:AST_L1A.003:2028324137 \\
\hline 21-Nov-07 & $09 \mathrm{~T}$ & Surface Radiance TIR & Night & SC:AST_L1A.003:2062848883 \\
\hline 22-Dec-07 & AST_07XT & Surface Reflectance VNIR & Day & SC:AST_L1A.003:2064011999 \\
\hline 23-Dec-07 & AST_09T & Surface Radiance TIR & Night & SC:AST_L1A.003:2064043505 \\
\hline 23-Dec-07 & L1B & Surface Radiance SWIR & Night & SC:AST_L1A.003:2064043505 \\
\hline 27-May-09 & AST_09T & Surface Radiance TIR & Night & SC:AST_L1A.003:2073834400 \\
\hline 30-Jul-09 & AST_09T & Surface Radiance TIR & Night & SC:AST_L1A.003:2075202177 \\
\hline 29-Jul-09 & AST_07XT & Surface Reflectance VNIR & Day & SC:AST_L1A.003:2075176798 \\
\hline 11 -Oct-10 & AST_09T & Surface Radiance TIR & Day & SC:AST_L1A.003:2081621953 \\
\hline 07-Dec-10 & AST_07XT & Surface Reflectance VNIR & Day & SC:AST_L1A.003:2082480246 \\
\hline 07-Dec-10 & 09T & Surface Radiance TIR & Day & SC:AST_L1A.003:2082480246 \\
\hline 23-Aug-13 & AST_009T & Surface Radiance TIR & Day & SC:AST_L1A.003:2126554976 \\
\hline 23-Aug-13 & AST_07XT & Surface Reflectance VNIR & Day & SC:AST_L1A.003:2126554976 \\
\hline 16-Feb-13 & 09T & Surface Radiance TIR & Night & SC:AST_L1A.003:2122809877 \\
\hline 30-Jan-14 & AST_07XT & Surface Reflectance VNIR & Day & SC:AST_L1A.003:2130529870 \\
\hline
\end{tabular}

minimum temperature range of at least $10-445^{\circ} \mathrm{C}$ for the BAF source rock, spanning $455^{\circ} \mathrm{C}$.

The 19 May 2001 BAF deposit (Fig. 5a) is long and narrow (485 m maximum deposit width). The flow followed the western edge of the 1964 debris avalanche deposit and has a total maximum length of $13.7 \mathrm{~km}$. The flow fanned out onto the dome talus slope until it reached the upper slide block, where it was then directed through a drainage bounding the slide block's western margin. At $5.0 \mathrm{~km}$ from the scar the deposit bifurcates, with a smaller lobe extending south for another $1.9 \mathrm{~km}$ before traveling farther southeast around Baidarny Ridge (location shown in Fig. 1). At the southern tip of Baidarny Ridge, a second smaller lobe extended southwest for an additional $1.3 \mathrm{~km}$. The main flow entered the Baidarnaya River channel $5.4 \mathrm{~km}$ from the scar where it traveled a further $8.2 \mathrm{~km}$. The total deposit area is $8.8 \mathrm{~km}^{2}$.
Lahar deposits extend beyond this point, resulting from the emplacement of the BAF onto snow.

\subsection{May 2004}

During an eruption on 10 May 2004, a portion of the southern flank of the Shiveluch dome collapsed to produce a scar with an aerial extent of $1.53 \mathrm{~km}^{2}$ (Fig. 4c-d). In an ASTER TIR scene acquired one day after the event, 42 pixels $\left(3.78 \mathrm{~km}^{2}\right)$ within the collapse scar are above the ASTER TIR saturation temperature of $97^{\circ} \mathrm{C}$, and the maximum detected SWIR temperature is $406^{\circ} \mathrm{C}$. The eruption deposited hot material on the eastern and western slopes of the dome and talus slope. Immediately below the dome, a section of the flow traveled up and over the western 1964 collapse crater rim and down a valley, emplacing another 3-km-long

Table 5

The summary of dome-collapse and BAF deposit parameters for the eight collapse events. The collapse scar is the area excavated during a collapse event.

\begin{tabular}{|c|c|c|c|c|c|c|c|c|c|c|c|}
\hline \multirow{2}{*}{$\begin{array}{l}\text { Event Date } \\
\text { 19-May-01 }\end{array}$} & \multirow{2}{*}{$\begin{array}{l}\text { Collapse scar area } \\
\left(\mathrm{km}^{2}\right)\end{array}$} & \multicolumn{2}{|c|}{$\begin{array}{l}\text { Collapse scar max. width } \times \\
\text { length }(\mathrm{m})\end{array}$} & $\begin{array}{l}\text { Dome Rock Removed } \\
\left(\mathrm{km}^{3}\right)\end{array}$ & \multicolumn{3}{|c|}{$\begin{array}{l}\text { BAF runout distance } \\
(\mathrm{km})\end{array}$} & \multicolumn{2}{|c|}{$\begin{array}{l}\text { BAF runout from dome } \\
\text { base }(\mathrm{km})\end{array}$} & \multirow{2}{*}{$\begin{array}{l}\text { Max. H/L } \\
\text { Ratio } \\
0.15\end{array}$} & \multirow{2}{*}{$\begin{array}{l}\text { BAF deposit area } \\
\left(\mathrm{km}^{2}\right)\end{array}$} \\
\hline & & $640 \times 750$ & & & $12.9-13$. & & & 10.9 & & & \\
\hline 10-May-04 & 1.53 & $800 \times 3500$ & & $0.004^{\mathrm{a}}$ & $5.7-8.8$ & & & 5.6 & & 0.20 & 11.4 \\
\hline 28-Feb-05 & 0.86 & $550 \times 2400$ & & $0.11^{\mathrm{b}}$ & $15.6-17$. & & & 15.4 & & 0.14 & 24.1 \\
\hline 18/19-Dec-07 & 1.4 & $840 \times 2650$ & & & $10-12.7$ & & & 9.8 & & 0.17 & 5.1 \\
\hline 25/26-Jun-09 & 0.46 & $580 \times 1260$ & & & $5.2-6.4$ & & & 3.8 & & 0.27 & 2.9 \\
\hline $27-O c t-10$ & 1.71 & $1100 \times 2540$ & & $0.28^{\mathrm{c}}$ & $16.4-19$ & & & 15.7 & & 0.13 & 22.3 \\
\hline 26-Jul-13 & 0.24 & $330 \times 1060$ & & & $10.6-11$. & & & 8.2 & & 0.18 & 3.5 \\
\hline 3 Dec 2013 & 0.4 & $550 \times 1100$ & & & $12.6-13$. & & & 9.7 & & 0.16 & 9.2 \\
\hline Event Date & $\begin{array}{l}\text { Max. deposit width } \\
(\mathrm{m})\end{array}$ & $\begin{array}{l}\text { Max. dome temp. } \\
\left({ }^{\circ} \mathrm{C}\right)\end{array}$ & $\begin{array}{l}\text { Dome no } \\
\text { saturatio }\end{array}$ & pixels above TIR & $\begin{array}{l}\text { Flow } \\
\text { direction }\end{array}$ & Lobes & $\begin{array}{l}\text { Cha } \\
\text { dep }\end{array}$ & $\begin{array}{l}\text { nnelized } \\
\text { osit }\end{array}$ & $\begin{array}{l}\text { Preceding } \\
\text { Anomaly }\end{array}$ & hermal & $\begin{array}{l}\text { Evidence for } \\
\text { surge? }\end{array}$ \\
\hline 19-May-01 & 485 & 445 & 10 & & SW & $\mathrm{N} / \mathrm{A}$ & $\mathrm{Y}$ & & $\mathrm{N} / \mathrm{A}$ & & $\mathrm{Y}$ \\
\hline 10-May-04 & 2500 & 406 & 42 & & $\mathrm{~S}$ & 4 & Mil & & $\mathrm{N} / \mathrm{A}$ & & $\mathrm{N}$ \\
\hline 28-Feb-05 & 2490 & 312.86 & 8 & & SW, W & 6 & Mil & & $\mathrm{Y}$ & & $\mathrm{Y}$ \\
\hline 18/19-Dec-07 & 1370 & 273.5 & 10 & & SW & 2 & $\mathrm{Y}$ & & $\mathrm{Y}$ & & $\mathrm{N}$ \\
\hline 25/26-Jun-09 & 1560 & $\mathrm{~N} / \mathrm{A}$ & 10 & & $\mathrm{~S}$ & 4 & $\mathrm{~N}$ & & $\mathrm{Y}$ & & $\mathrm{N}$ \\
\hline $27-$ Oct-10 & 4100 & $\mathrm{~N} / \mathrm{A}$ & $\mathrm{N} / \mathrm{A}$ & & S, SE & $\mathrm{N} / \mathrm{A}$ & $\mathrm{Y}$ & & Y & & $\mathrm{Y}$ \\
\hline 26-Jul-13 & 1100 & $\mathrm{~N} / \mathrm{A}$ & 2 & & SW & 3 & $\mathrm{Y}$ & & Y & & $\mathrm{N}$ \\
\hline 3 Dec 2013 & 1550 & $\mathrm{~N} / \mathrm{A}$ & 3 & & SW & 5 & $\mathrm{Y}$ & & Y & & $\mathrm{N}$ \\
\hline
\end{tabular}

a Zharinov and Demyanchuk, 2008.

b Shevchenko and Svirid, 2014.

c Dvigalo et al., 2011; Shevchenko et al., 2015. 
Table 6

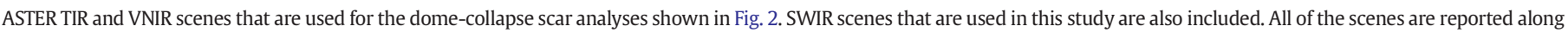
with the number of days that the scene was acquired after the eruption/collapse event (days after eruption).

\begin{tabular}{|c|c|c|c|c|c|c|c|}
\hline Figure & Eruption date & TIR scene date & Days after eruption & VNIR scene date & Days after eruption & SWIR scene date & Days after eruption \\
\hline $3 a-b$ & 19-May-01 & 19-Мay-01 & 0 & 14-Feb-02 & 271 & 19-May-01 & 0 \\
\hline $3 c-d$ & 10-May-04 & 11-May-04 & 1 & 4-Jun-04 & 26 & 4-Jun-04 & 26 \\
\hline $3 e-f$ & 27/28-Feb-05 & 12-Mar-05* & 4 & 12-Mar-05 & 13 & 29-Mar-05 & 29 \\
\hline $3 \mathrm{~g}-\mathrm{h}$ & 18/19-Dec-07 & 23-Dec-07 & 6 & 22-Dec-07 & 5 & 23-Dec-07 & 1 \\
\hline $3 i-j$ & 25/26-Jun-09 & 30-Jul-09 & 36 & 29-Jul-09 & 35 & $\mathrm{~N} / \mathrm{A}$ & \\
\hline $3 \mathrm{k}-1$ & $27-O c t-10$ & $7-$ Dec-10* & 42 & 7-Dec-10 & 42 & $\mathrm{~N} / \mathrm{A}$ & \\
\hline $3 m-n$ & 26-Jul-13 & 23-Aug-13* & 28 & 23-Aug-13 & 28 & $\mathrm{~N} / \mathrm{A}$ & \\
\hline $30-p$ & 3-Dec-13 & 16-Feb-14 & 133 & 30-Jan-14 & 59 & $\mathrm{~N} / \mathrm{A}$ & \\
\hline
\end{tabular}

* ASTER TIR day time image.

deposit over an area of $1.42 \mathrm{~km}^{2}$. The majority of the material traveled to the east of the slide blocks and then continued south to produce a fanshaped deposit with a maximum width of $\sim 2.5 \mathrm{~km}$ and a total area of $11.4 \mathrm{~km}^{2}$ (Fig. 5b). The main body of the deposit terminates with four lobes, with each lobe extending out to a further $1 \mathrm{~km}$ in length. The maximum runout length is $8.8 \mathrm{~km}$.

\section{3. $27-28$ February 2005}

Prior to the 27-28 February 2005 eruption, a SWIR scene acquired on 23 February show three areas with elevated temperatures on the western side of the dome. Retrospective analysis of these data show that these areas largely coincide with the area of subsequent collapse. Data acquired five days after the eruption show that the dome collapse formed an elongate scar cutting into the southeast portion of the dome. This scar has an area of $0.86 \mathrm{~km}^{2}$ and maximum dimensions of $0.55 \times 2.4 \mathrm{~km}$ (Fig. 4e-f). The uppermost area of the collapse scar occurs in the region of the thermal anomalies that were present prior to the collapse. The scar has a central elongate trough up to $170-\mathrm{m}$-wide and $2.1 \mathrm{~km}$ long. Above this trough are lateral terraces, $\sim 160-\mathrm{m}$-wide and $\sim 1.2-\mathrm{km}$-long along the eastern side, and a smaller western terrace with maximum dimensions of 65 -m-wide by 0.6-km-long. Within the scar, TIR data acquired on 12 March (four days after the eruption) show eight pixels corresponding to an area of $720 \mathrm{~m}^{2}$ above the saturation temperature of $97^{\circ} \mathrm{C}$; whereas, the ASTER SWIR data acquired on 29 March contain pixels within the scar area that have a maximum temperature of $312{ }^{\circ} \mathrm{C}, 29$ days after the eruption occurred.

The 27-28 February 2005 BAF traveled through the western drainage system and continued to the south and southwest for a distance of $17.8 \mathrm{~km}$ from the dome scar (Fig. 5c). Below the dome, a smaller portion of the flow overtopped the eastern side of the western drainage system and deposited a lobe that extends south for $2 \mathrm{~km}$. The main flow traveled to the southwest alongside the Baidarnaya River, then fanned out and emplaced the upper fan deposits with a maximum width of $\sim 2.5 \mathrm{~km}$. At a distance of $10.3 \mathrm{~km}$ from the dome scar, the deposit is largely confined to the $\sim 190$-m-wide Baidarnaya River channel for a distance of $\sim 2 \mathrm{~km}$ towards the west, before fanning out and emplacing the lower fan deposit that has a maximum width of $2.04 \mathrm{~km}$. This main lower fan deposit terminates with five lobes, each with a length of as much as $2 \mathrm{~km}$ long. At $10.8 \mathrm{~km}$ from the dome scar, a portion of the BAF overtopped the channel and continued towards the southwest for another 4.2 to $5 \mathrm{~km}$. This smaller deposit section has a maximum width of $900 \mathrm{~m}$, and an area of $1.9 \mathrm{~km}^{2}$. The entire BAF deposit covers an area of $24.1 \mathrm{~km}^{2}$. The main $2005 \mathrm{de}-$ posit fan is surrounded by a rim of dead trees reaching $300 \mathrm{~m}$-wide, that were killed by a fine-grained pyroclastic surge that continued past the main BAF deposition area. This rim is clearly visible in all of the available satellite wavelengths and has sharp boundaries marking the BAF deposit-surge area boundary, and the surge arealiving trees boundary.

\subsection{8-19 December 2007}

The 18-19 December 2007 collapse event occurred along the western side of the dome and talus slope within the area of the 27-28 February 2005 collapse (Fig. 4g-h). Prior to the collapse, a thermal anomaly was visible near the summit of the dome in the area that would become the upper area of the dome collapse scar. The VNIR and TIR data show the collapse scar with an area of $1.4 \mathrm{~km}^{2}$. Within the dome scar, ten pixels corresponding to an area of $900 \mathrm{~m}^{2}$ exceed the ASTER TIR $97^{\circ} \mathrm{C}$ saturation temperature, six days after the collapse. The maximum SWIR-derived temperature is $273.5^{\circ} \mathrm{C}$ within the collapse scar.

The BAF that was produced during the collapse was directed to the east of the 1964 slide blocks, where it fanned out to form a deposit with a length of $4.5 \mathrm{~km}$ and a maximum width of $1.37 \mathrm{~km}$ (Fig. 5d). At the southern tip of the Baidarny Ridge, $6.5 \mathrm{~km}$ from the scar, the BAF turned towards the west for a short distance, and then towards the south where it continued along the edge of the 1964 debris avalanche fan. The flow was confined within the Baidarnaya River channel for $7 \mathrm{~km}$ and ultimately formed a $5.1 \mathrm{~km}^{2}$ deposit, with a maximum runout distance of $12.7 \mathrm{~km}$. VNIR data acquired before the collapse show that prior to the dome collapse and BAF emplacement, the top of the 27-28 February 2005 scar had largely been filled by a $670 \times 900 \mathrm{~m}$ dome and associated talus material.

\subsection{5-26 June 2009}

The BAF deposit emplaced during the 25-26 June 2009 eruption is the smallest out of the deposits included in this study. In our retrospective examination of TIR data that was acquired on 27 May 2009, we detected an elongate thermal anomaly that measures $\sim 0.45 \times 1.33 \mathrm{~km}$ on the upper-southern dome slope. The 25-26 June 2009 collapse area coincided almost exactly with the location of this pre-existing thermal anomaly, producing a scar with an area of $0.46 \mathrm{~km}^{2}$ (Fig. $4 \mathrm{i}-\mathrm{j}$ ). In a scene acquired four days after the eruption, ten pixels within the dome scar $\left(900 \mathrm{~m}^{2}\right)$ exceed the $97^{\circ} \mathrm{C}$ ASTER TIR saturation temperature.

The resulting BAF was directed through the eastern drainage system and emplaced material to the south, over an area of $2.9 \mathrm{~km}^{2}$ (Fig. $5 \mathrm{e}$ ). The runout length reaches a maximum distance of $6.4 \mathrm{~km}$ from the dome scar and it has a maximum width of $1.56 \mathrm{~km}$. The deposit area terminates in four lobes. The eastern-most lobe flowed up and over a topographic high at a bend in the drainage below the dome, located $4.4 \mathrm{~km}$ from the dome scar, while the other three lobes extend downslope from the deposit fan.

\subsection{October 2010}

In our retrospective analysis of TIR data acquired on 11 October 2010, 16 days before the 27 October eruption, we identified a $640 \times 645 \mathrm{~m}$ thermal anomaly near the summit of the dome. The subsequent collapse produced a $1.1 \times 2.54 \mathrm{~km}$ scar along the eastern side of the dome and talus slope, with an area of $1.71 \mathrm{~km}^{2}$ (Fig. 4k-1). The thermal anomaly 
that precedes the collapse date is located near the center of this scar area. The maximum depth of the dome collapse scar was $\sim 180 \mathrm{~m}$, calculated here from a photogrammetry-derived DEM published by Shevchenko et al. (2015).

The 27 October 2010 eruption produced a BAF deposit that covered a total area of $22.3 \mathrm{~km}^{2}$ (Fig. 5f). The deposit includes three distinct depositional areas: 1 ) an area of relatively thin and patchy deposition in the proximal area that extends to $\sim 10.6 \mathrm{~km}$ from the dome scar; 2 ) the main deposit fan that extends from $\sim 10.6$ to $\sim 16.2 \mathrm{~km}$ from the dome scar; and 3) a channelized deposit within the Kabeku River channel (location given in Fig. 1a) for an additional $5.4 \mathrm{~km}$ to the east. In the proximal deposit area, two lobes were emplaced over the eastern scarp of the 1964 collapse crater to distances of 4 and $7.5 \mathrm{~km}$. The total length of the 2010 deposit, including the channelized section, reaches a maximum of
$19.0 \mathrm{~km}$ from the dome collapse scar. The main deposit fan covers an area of $16.2 \mathrm{~km}^{2}$, with $11.6 \mathrm{~km}^{2}$ of this area emplaced on top of the 1964 debris avalanche deposit. The entire deposit has a maximum width of $4.1 \mathrm{~km}$. The distal edge of the main deposit fan is defined by the continuation of the flow for an additional 0.4 to $1 \mathrm{~km}$ into linear furrows or depressions in the underlying 1964 debris avalanche deposit. There is evidence of a dilute surge cloud component from the October 2010 BAF in the Kabeku River channel, as shown by the trees killed on the hillsides surrounding the channel.

\subsection{July 2013}

The 26 July 2013 dome-collapse event occurred on the northwest flank of the dome, producing the smallest collapse scar that is observed
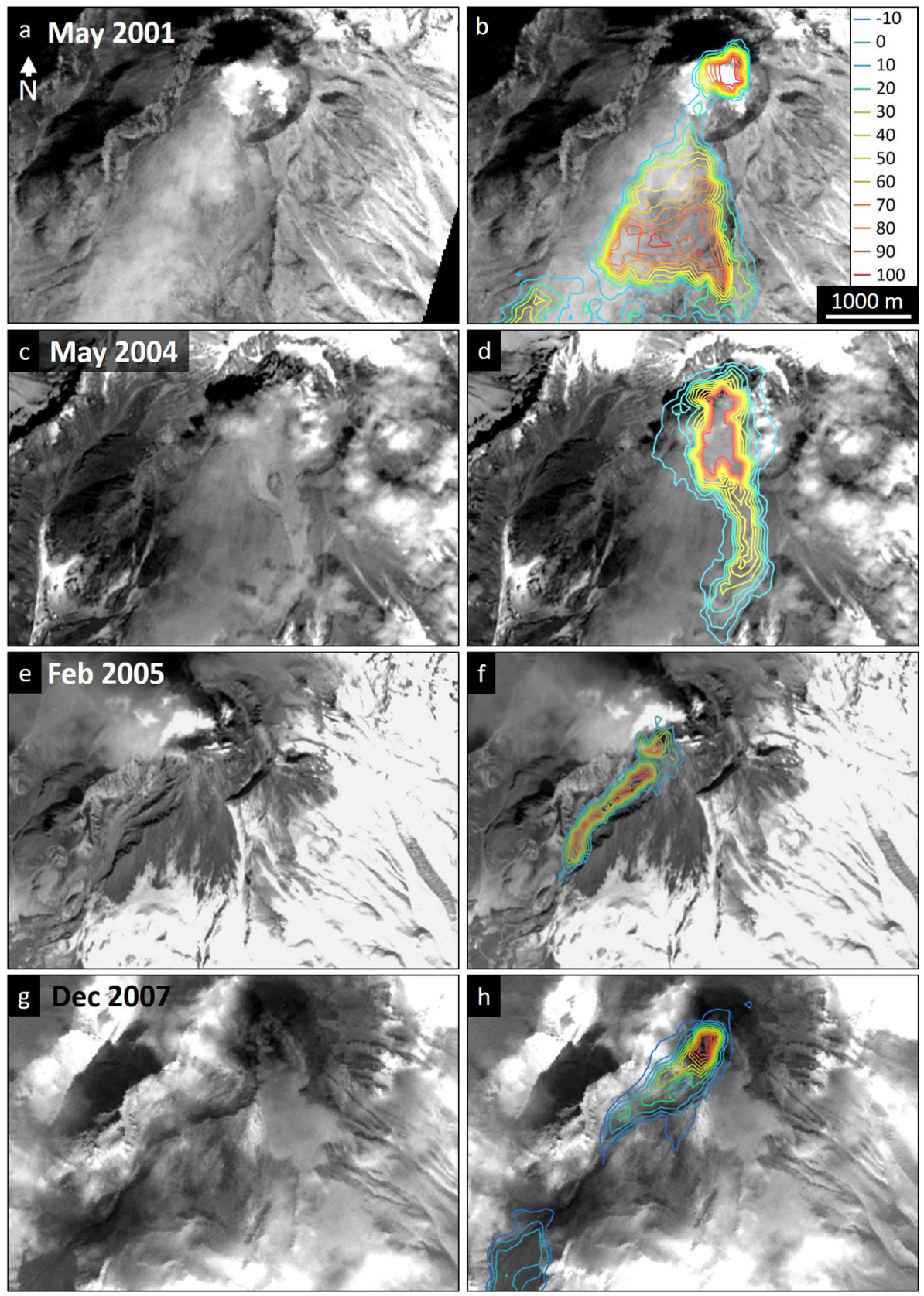

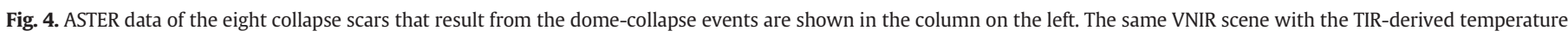

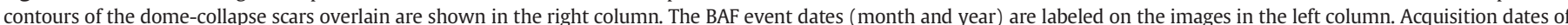

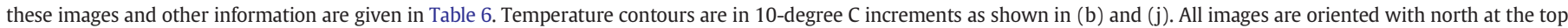

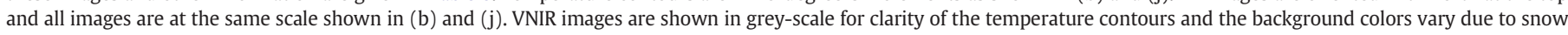
and ash cover on the volcano at the time of acquisition. 

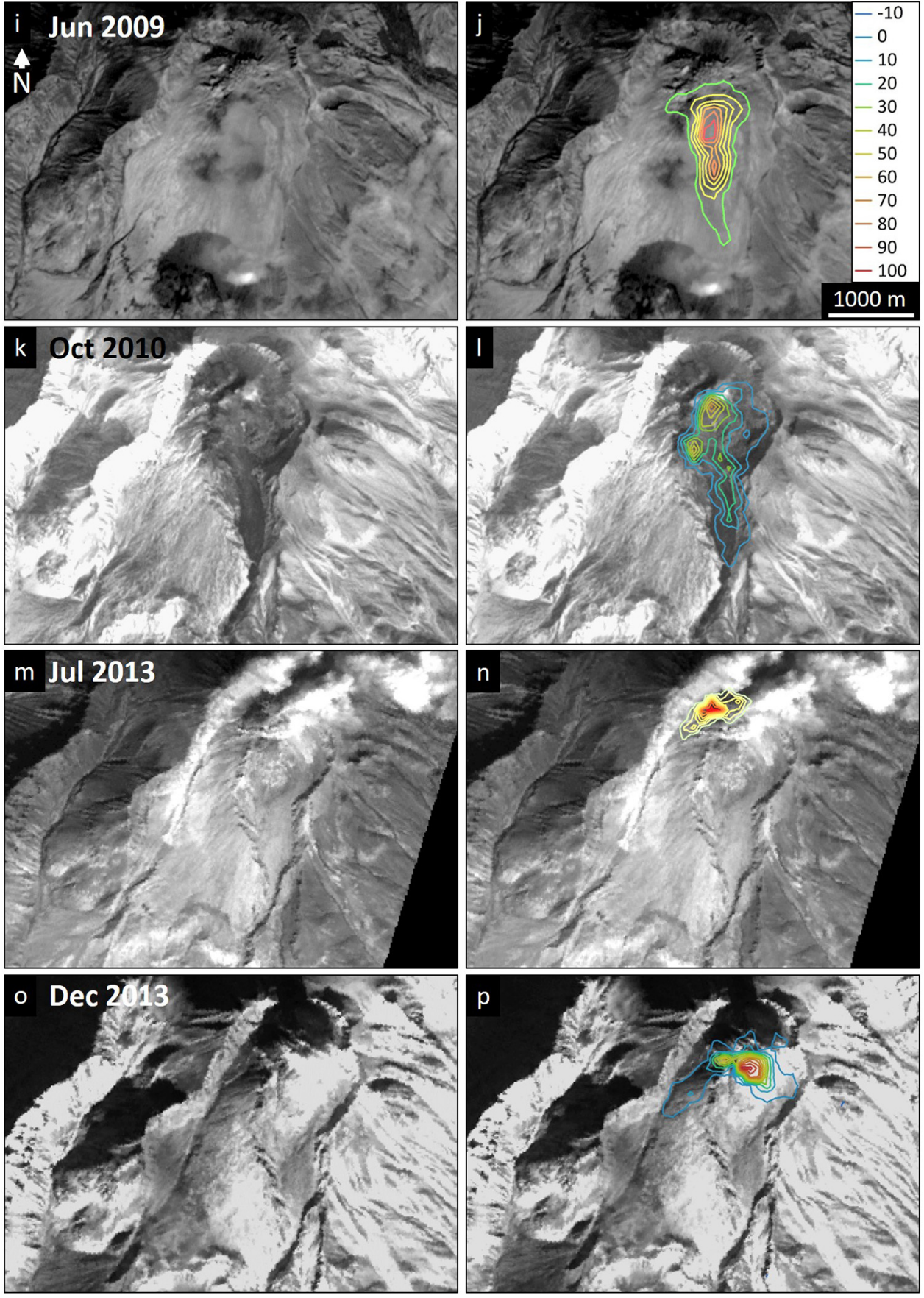

Fig. 4 (continued).

in this study, with an area of only $0.24 \mathrm{~km}^{2}$ (Fig. $4 \mathrm{~m}-\mathrm{n}$ ). In ASTER data acquired prior to the eruption, steam can be seen emanating from the collapse area. Elevated temperatures surround the future collapse area, although other areas of the dome that did not undergo collapse also display elevated temperatures (above background temperature). Within the dome collapse scar, two pixels that cover an area of $180 \mathrm{~m}^{2}$ exceed the $97{ }^{\circ} \mathrm{C}$ ASTER TIR saturation threshold in a scene that was acquired on 23 August 2013. The hottest area is located near the center of the 2013 dome scar.

The BAF that resulted from this collapse traveled down the western side of the dome and through the western drainage system. The flow emplaced material to the southwest of the dome alongside the Baidarny Ridge and farther south down the Baidarnarya River channel (Fig. 5g). The portion of the flow that emplaced the main deposit body fanned out below the dome and terminated in three distal lobes. This main deposit fan has a total length of 3 to $4.3 \mathrm{~km}$, and a maximum width of $1.1 \mathrm{~km}$. The distal portion of the BAF was channelized within the Baidarnaya River channel. The flow entered the channel at a distance of $6.3 \mathrm{~km}$ from the dome scar and continuing for $4.65 \mathrm{~km}$ downstream. It is evident that the flow underwent superelevation where the flow traveled up and over the confining channel walls at $7.9 \mathrm{~km}$ from the dome, after a bend in the channel, and again at $9.9 \mathrm{~km}$ where the channel is shallower. The maximum total length of the deposit measures $11.6 \mathrm{~km}$ from the dome scar, and it covers a total area of $3.5 \mathrm{~km}^{2}$. It is uncertain whether the 2013 deposit was entirely emplaced during the 26 July eruption, or if it also includes material produced by subsequent activity in August (KVERT online report, 31-2013), as cloud cover prevented data acquisition during the weeks following the eruption. 

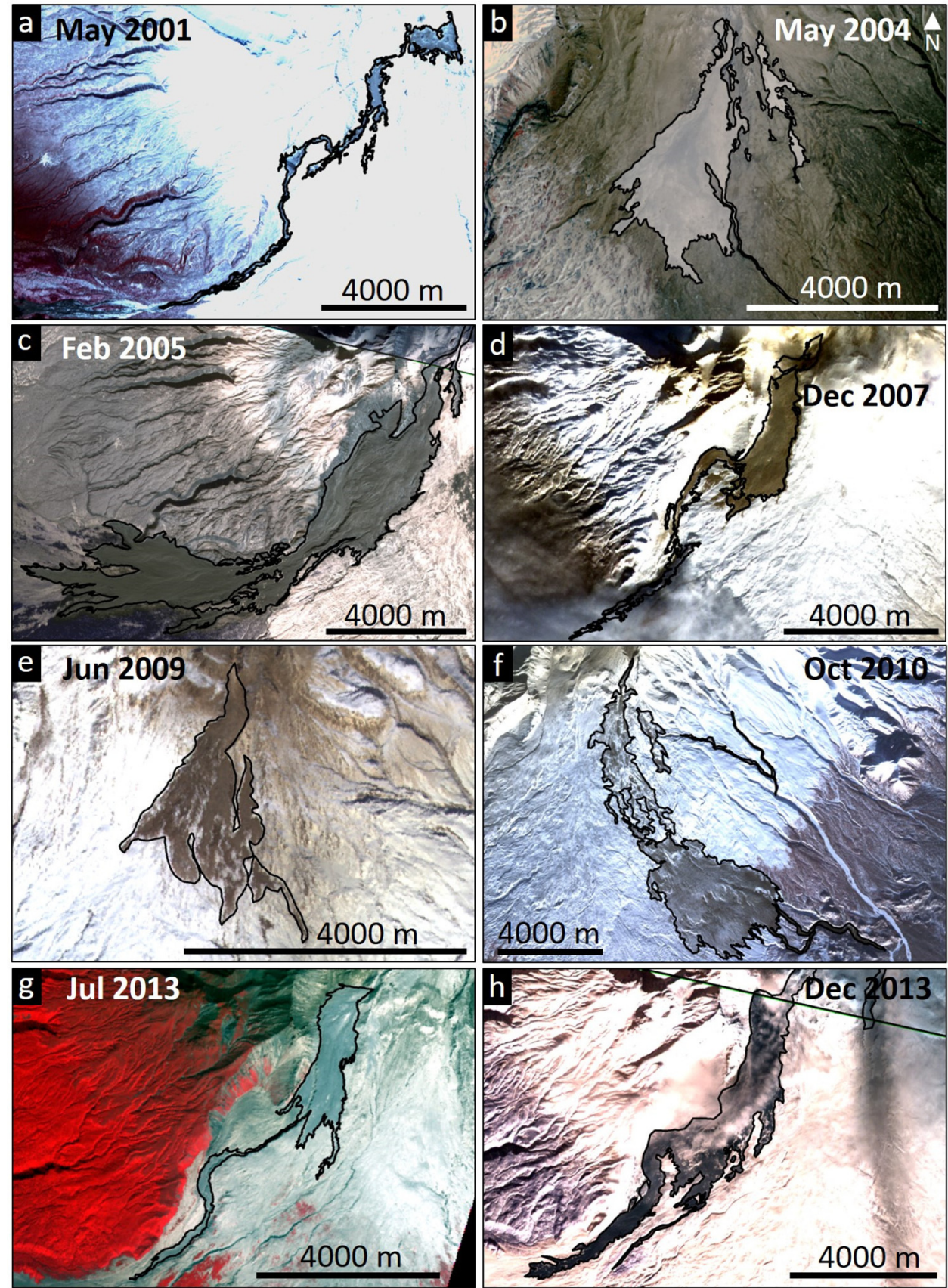

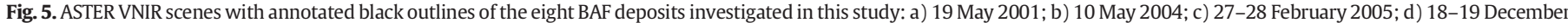
2007; e) 25-26 June 2009; f) 27 October 2010; g) 26 July 2013; h) 3 December 2013.

\subsection{December 2013}

The 3 December 2013 BAF was the result of a dome-collapse event originating on the northeastern section of the dome (Fig. 4o-p), in the same location as the 19 May 2001 and 26 July 2013 collapse events. TIR data acquired on 16 February 2014 (133 days after the collapse) register an elevated thermal signature on the dome scar approximately $0.4 \mathrm{~km}^{2}$ in size in this location, with maximum dimensions of $\sim 1.1 \times$ $\sim 0.55 \mathrm{~km}$. Three pixels with an area of $270 \mathrm{~m}^{2}$ exceed the ASTER TIR saturation threshold of $97^{\circ} \mathrm{C}$, but due to the elapsed time after the collapse it is not certain that this is a direct result of the collapse.

The resulting BAF traveled down the southwest side of the dome, with a small portion of the flow traveling down the eastern side of the dome and producing a 3.4-km-long deposit on the dome and talus slope. This is identified by an elevated thermal signature in the postcollapse ASTER TIR scene. The bulk of the BAF exited the western draining system and produced a $5.3 \mathrm{~km}$ to $8.6 \mathrm{~km}$ long deposit fan. To the southeast of the main fan, a narrow portion of the flow continued down the Baidarnaya River channel to a maximum runout distance of $13.6 \mathrm{~km}$ (Fig. 5h). A smaller portion of the flow emplaced an additional long and narrow deposit to $2.3 \mathrm{~km}$ from the southeast edge of the main deposit body, reaching $11.6 \mathrm{~km}$ from the dome scar. The entire deposit has a maximum width of $1.5 \mathrm{~km}$ and covers an area of $9.2 \mathrm{~km}^{2}$.

This BAF was imaged at one-minute intervals by a webcam housed at the Kamchatkan Volcanological Station in Klyuchi village, $45 \mathrm{~km}$ to the SSW of the dome and $30 \mathrm{~km}$ from the southern edge of the deposit fan. These images show five smaller BAF pulses over a time span of $2 \mathrm{~h}$, then a larger BAF pulse that emplacement the main deposit fan. Over 
the $3 \mathrm{~h}$ of the eruption event that was imaged during daylight hours (13:13 to $16: 07$, local time) there were at least six pulses of collapse, with only three of those at 13:21,13:42, and 14:14 appearing to transport material to the distal edge of the deposit. The smaller initial flows did not extend beyond the southern tip of Baidarny Ridge located $6.6 \mathrm{~km}$ from the dome scar. Fig. 2 shows one of these BAF pulses moving alongside Baidarny Ridge. Smaller avalanches or flows continued into the night.

\section{Discussion}

Around the world, recent extended periods of dome growth and collapse have occurred at Soufrière Hills volcano on Montserrat from 1995 to 2010 (e.g. Wadge et al., 2014), Unzen volcano in Japan in 1990 to 1995 (e.g. Tadahide et al., 1999; Miyabuchi, 1999), and Sinabung volcano, Indonesia from December 2013 to present (Gunawan et al., 2017; Pallister et al., 2017), among others. Similar activity is ongoing at Shiveluch volcano and eight large dome-collapse events and their BAF deposits are detailed here to evaluate the relationships between dome collapse events and deposit distribution. Analysis of these events examines the potential impact of large BAFs by documenting the variability of dome-collapse and the related BAF deposit distribution over the course of a long-lived dome-forming eruption. The identification of systematic patterns of BAF emplacement over prolonged eruption durations, like at Shiveluch, could reduce uncertainty in evaluating risk at other dome-building volcanoes around the world (Ogburn et al., 2015). However, for such patterns to be useful in hazard evaluations they must be statistically robust, requiring additional studies spanning across dome forming eruptions.

\subsection{Dome-collapse BAF deposits on Shiveluch}

The recent deposits produced on Shiveluch volcano are predominantly of the BAF type. This is confirmed by field investigations of the 2005 and 2010 deposits during a field campaign in 2015, and an earlier study carried out by Shevchenko and Svirid (2014). The 2005 and 2010 deposits comprise an ash and lapilli-supported matrix with sub-angular to sub-rounded blocks up to $12 \mathrm{~m}$ in diameter. The predominant material is dome rock, with minor entrained accidental clasts from the underlying 1964 pyroclastic flow deposits and trees that were felled by the flows. Shevchenko and Svirid (2014) examined the dome collapse scars produced in May 2004, December 2007, and October 2010. They identified collapse scarps, strongly tapering-downward scars, and lack of explosion craters. The authors concluded that these were due to gravitational processes rather than explosive eruptions, even though some events were accompanied by explosive activity. The last confirmed pyroclastic flow that was generated by column collapse occurred in 1964 during an eruption that produced a Plinian ash column, when there was no dome present (Belousov, 1995). Based on these observations, we make the assumption that all BAF deposits studied here are largely due to dome-collapse rather than column collapse, with possible minor contributions from column collapse. Evidence of ash plumes associated with the collapse events are seen in several satellite images. Lightning strikes associated with these ash plumes were recorded by the World Wide Lightning Location Network (WWLN) during the February 2005, June 2009, and October 2010 events (over 11 min, 17 h, and $1.5 \mathrm{~h}$, respectively). Earlier field work noted pumiceous components in the May 2001 and July 2013 deposits, suggesting that partial collapse of dome material in some cases may have exposed deep or fresh parts of the dome underwent vesiculation due to gravitational unloading.

\subsection{Pre-eruption thermal anomalies}

Retrospective examination of precursory thermal anomalies over the eight eruption events was undertaken to assess the ability of forecasting dome collapse events using satellite TIR data at Shiveluch. Using data acquired prior to six of the eight events (where TIR data was available), TIR pixel-integrated brightness temperature data were analyzed for areas of elevated thermal output occurring within, or partially overlapping, the areas dome-collapse (Fig. 6). For all six events, thermal anomalies were identified within the areas of the future collapse. Most of the areas of elevated temperatures that precede the collapse events are smaller than the collapse areas, except for the thermal anomaly preceding the June 2009 event that almost exactly marks the area (size and location) of the future collapse. Increased thermal output on a lava dome can be the result of heat radiating outward from cracks that form as magma moves towards the surface, lava extrusion onto the surface, active faults that reach the surface, increased fumarole temperatures, or the exposure of inner, hotter material by collapse or explosions (e.g., Kaneko et al., 2002; Schneider et al., 2008; van Manen et al., 2010; Bernstein et al., 2013; Wessels et al., 2013). Gravitational sliding processes that result in fault movement and headwall fractures have previously been described at Shiveluch (Shevchenko and Svirid, 2014). The formation of headwall scarps may account for the thermal anomalies preceding the collapse events, especially the events where the anomaly occurs at the top of the subsequent collapse. Effusion of fresh, hot material onto the dome could also cause, or contribute to, these anomalies.

Here, we discuss the limitations of using these data for thermal precursory analysis and forecasting of collapses. These pre-eruption thermal data are based on a single data point (one ASTER TIR scene) for each eruption since data are limited to only a few data acquisition times during the days to weeks preceding and the collapse events that followed. Cloud cover and gas and steam plumes over the dome area further reduces the ability to retrieve dome surface temperatures. Based on the results of this study, it would be difficult to forecast deposit area and extent based on the surficial manifestations of dome activity, such as areas of elevated thermal activity. The surface expression of thermal radiation does not indicate the potential depth instability of dome material, and therefore, the volume of dome collapse material cannot be determined in advance of an eruption using this method. An additional problem with long-lived dome-forming eruptions is the frequent occurrence of thermal anomalies on the dome surface that do not lead to collapse events. The KVERT online reports commonly note persistent thermal anomalies over the area of the lava dome at Shiveluch that are not associated with collapse events. Between the dates 19 May 2001 to 6 December 2013 there were 287 ASTER TIR scenes showing elevated temperatures on the dome. This includes scenes only partly covering the dome, and scenes containing thin cloud or gas/steam through which the thermal anomaly is visible. Satellite observations of the dome surface are limited by the overpass frequency (how often data is acquired over a given location) and the number of scenes that are free of atmospheric cloud and gas/steam plumes that obscure the dome area. For a complete evaluation of the value of thermal imaging for identifying areas that are susceptible to collapse, a higher density of data is needed leading up to an eruption (either satellite- or ground-based). If such data were available, it would allow the quantification of the changes in thermal intensity through time in pre-collapse areas. To improve the understanding and applicability of the link between thermal anomalies to active lava extrusion, the integration of additional monitoring datasets such as seismicity, gas flux measurements, and deformation data is recommended. Quantifying the relative roles of active dome-growth processes, as opposed to other external factors (e.g. gravitational failure), is important for forecasting efforts.

\subsection{BAF deposit distributions}

Over the investigation period, the BAF maximum runout distances vary from 6.4 to $19.0 \mathrm{~km}$, producing deposits that range in area from 3.5 to $24.1 \mathrm{~km}^{2}$. Additional associated surge deposits occur in the May 
24 February 2005

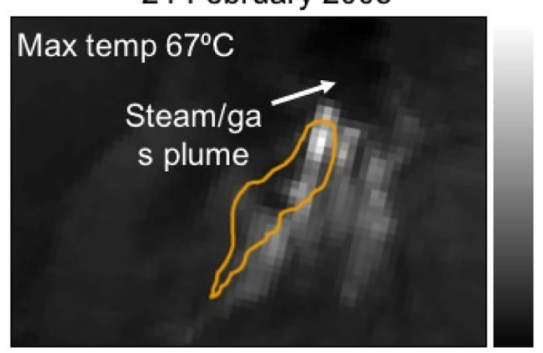

27 May 2009

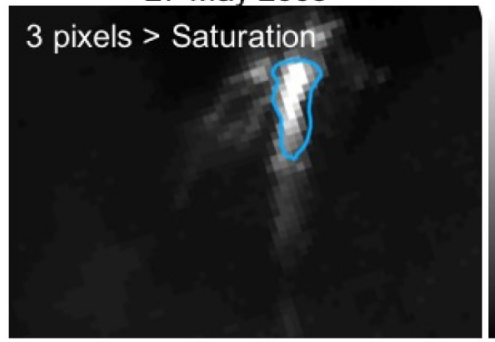

9 July 2013

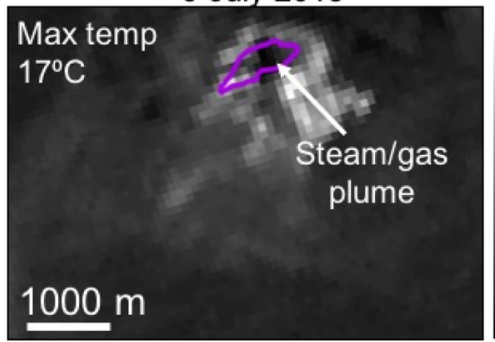

21 November 2007
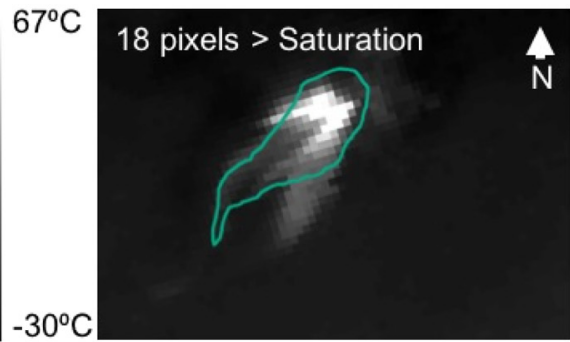

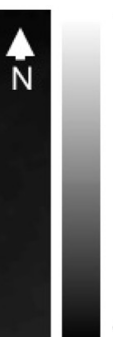

$107^{\circ} \mathrm{C}$

$-27^{\circ} \mathrm{C}$

11 October 2010

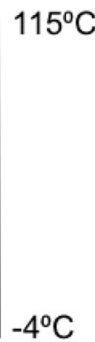

6 pixels $>$ Saturation

$114^{\circ} \mathrm{C}$

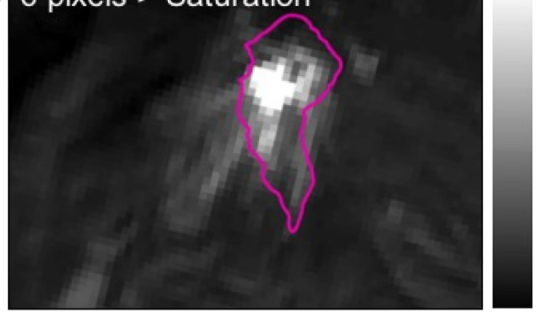

$-9^{\circ} \mathrm{C}$

30 November 2013

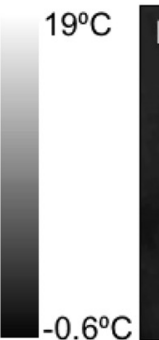

$76^{\circ} \mathrm{C}$

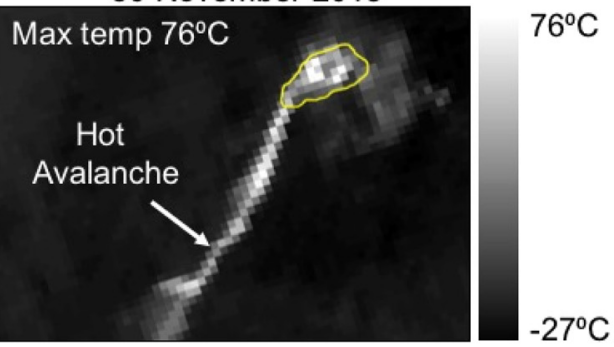

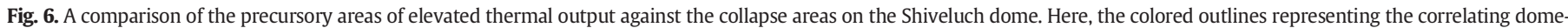

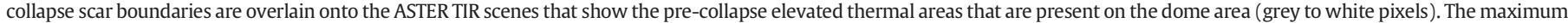

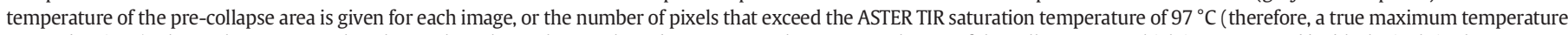

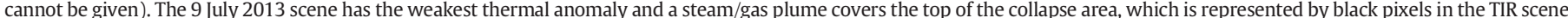

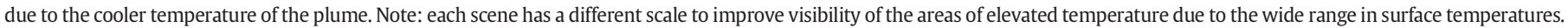

2001, February 2005, and October 2010 deposits, extending up to $300 \mathrm{~m}$ beyond the main deposit boundaries. These larger BAF runout distances are significant in comparison to collapse events and deposits at other volcanoes around the world (Table 7). The 2005 and 2010 BAF deposits are the two largest at Shiveluch, in both runout distance and deposit area, and are two of the largest known historical deposits on any volcano. Prior to data published in 2015, the largest known historical dome-collapse volume was the 12-13 July 2003 failure of the Soufrière

Table 7

BAF maximum runout distance and maximum deposit area for Shiveluch (this study) and other dome-producing volcanoes around the world.

\begin{tabular}{|c|c|c|c|c|}
\hline Volcano & Eruption Date & Max. BAF runout distance $(\mathrm{km})$ & Max. Deposit Area $\left(\mathrm{km}^{2}\right)$ & Reference \\
\hline \multirow[t]{8}{*}{ Shiveluch } & 19-May-2001 & 13.7 & 3.5 & \\
\hline & 10-May-2004 & 8.8 & 11.4 & \\
\hline & 28-Feb-2005 & 17.8 & 24.1 & \\
\hline & 18/19-Dec-07 & 12.7 & 5.1 & \\
\hline & 25/26-Jun-09 & 6.4 & 2.9 & \\
\hline & 27-Oct-2010 & 19 & 22.3 & \\
\hline & 26-Jul-2013 & 11.6 & 3.5 & \\
\hline & 3-Dec-2013 & 1 & 9.2 & \\
\hline \multirow[t]{4}{*}{ Merapi } & 18/19-Dec-30 & 13.2 & 8.5 & Bourdier and Adburachman, 2001; Ogburn, 2012. \\
\hline & 7/8-Jan-69 & 13 & 7.8 & Bourdier and Adburachman, 2001; Ogburn, 2012. \\
\hline & 14-Jun-2006 & 7.8 & 1.136 & Thouret et al., 2010; Thouret et al., 2015 \\
\hline & 5-Nov-2010 & 15.5 & 6.53 & Surono et al., 2012, Charbonnier et al., 2013; Solikhin et al., 2015 \\
\hline Unzen & 1990-1995 & 5.5 & & Miyabuchi, 1999 \\
\hline Tarawera & $1305 \mathrm{CE}$ & 9.4 & & Nairn et al., 2001; Hanenkamp, 2011 \\
\hline Chaiten & 19-Feb-2009 & 6 & & Major et al., 2013 \\
\hline Soufriere Hills** & $1995-2010$ & 7 & 10 & Cole et al., 2002; Sparks et al., 2002 \\
\hline Sinabung & 2010-2015 & 4.9 & & Yulianto et al., 2016; Nakada et al., 2017; Pallister et al., 2017 \\
\hline Augustine ${ }^{* *}$ & Jan-Mar 2006 & 5 & $4.42^{*}$ & Vallance et al., 2010 \\
\hline Colima & 19-Jan-1913 & 15 & 0.07 & Saucedo et al., 2005 \\
\hline
\end{tabular}

\footnotetext{
* Area includes all deposit components (block and ash flow plus surge).
}

** Flows entered the sea, therefore, runout distances are minimum values. 


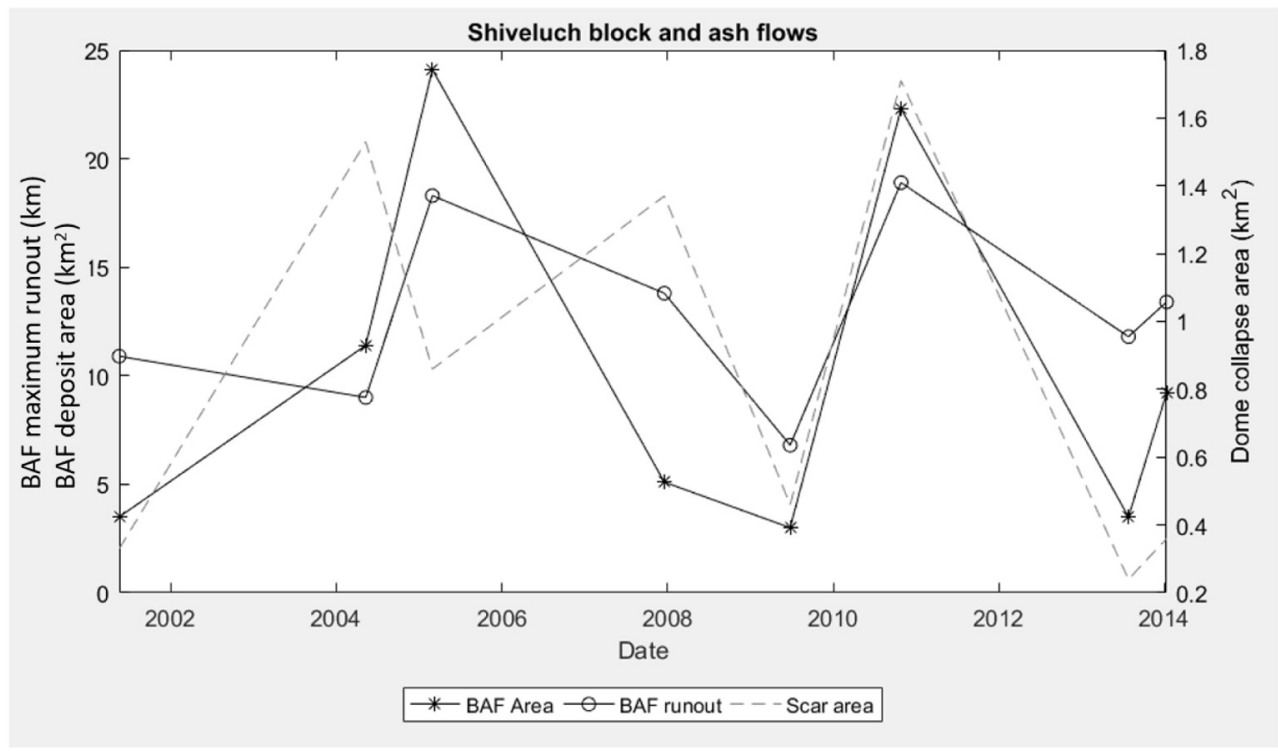

Fig. 7. The BAF areas $\left(\mathrm{km}^{2}\right)$, runout distances $(\mathrm{km})$, and planimetric dome-collapse areas (scar area, $\left.\mathrm{km}^{2}\right)$ of the eight collapse events.

Hills volcano dome with a volume of $0.21 \mathrm{~km}^{3}$ (Herd et al., 2005). The October 2010 collapse exceeds this with a volume of $0.28 \mathrm{~km}^{3}$ as calculated by Dvigalo et al., 2011 (Shevchenko et al., 2015). This volume does not take into account bulking processes (increasing in volume) by the entrainment of accidental material during flow transportation.

Data for volcanoes other than volcanoes sourced from Ogburn (2012) and Harnett et al. (2017).

Although the results of this study show a relationship between deposit area/runout distance and the dome-collapse scar areas from 2001 to 2009, a much stronger relationship emerges after 2009 (Fig. 7). The lack of a simple relationship between area of the collapse scars and the area and runout of the resulting BAFs in our data suggest that additional controlling factors are involved, such as the depth of instability (in addition to the surficial area) of the dome rock that is a main factor controlling the BAF volume, and the runout distance, which is also affected by the transportation path geometry that the flow takes (i.e. channelized or open area). This is reflected in the $\mathrm{H} / \mathrm{L}$ values, which range from 0.13 to 0.27 . $\mathrm{H} / \mathrm{L}$ values have been used to compare the mobility of granular flows across uniform surfaces (e.g., Hayashi and Self, 1992) but the wide range for Shiveluch flows supports the hypothesis that the channelization of the flows exerts a profound influence on runout distance. The May 2004 and December 2007 collapse events produced relatively large collapse scars on the dome, which could be due to a shallow collapse depth over a broad area. The February 2005 collapse event produced a deep collapse scar on the dome and resulted in a relatively small scar area. The depths of dome-collapse scars on Shiveluch should be quantified and compared to deposit area and runout distance for further analysis. Channelization of the flow enhanced the runout distance of the May 2001, December 2007, October 2010, July 2013, and December 2013 BAFs. During these events, the flows continued for over $5 \mathrm{~km}$ beyond the main fan deposits, with the length of the channelized deposit accounting for up to $60 \%$ of the total deposit length. The

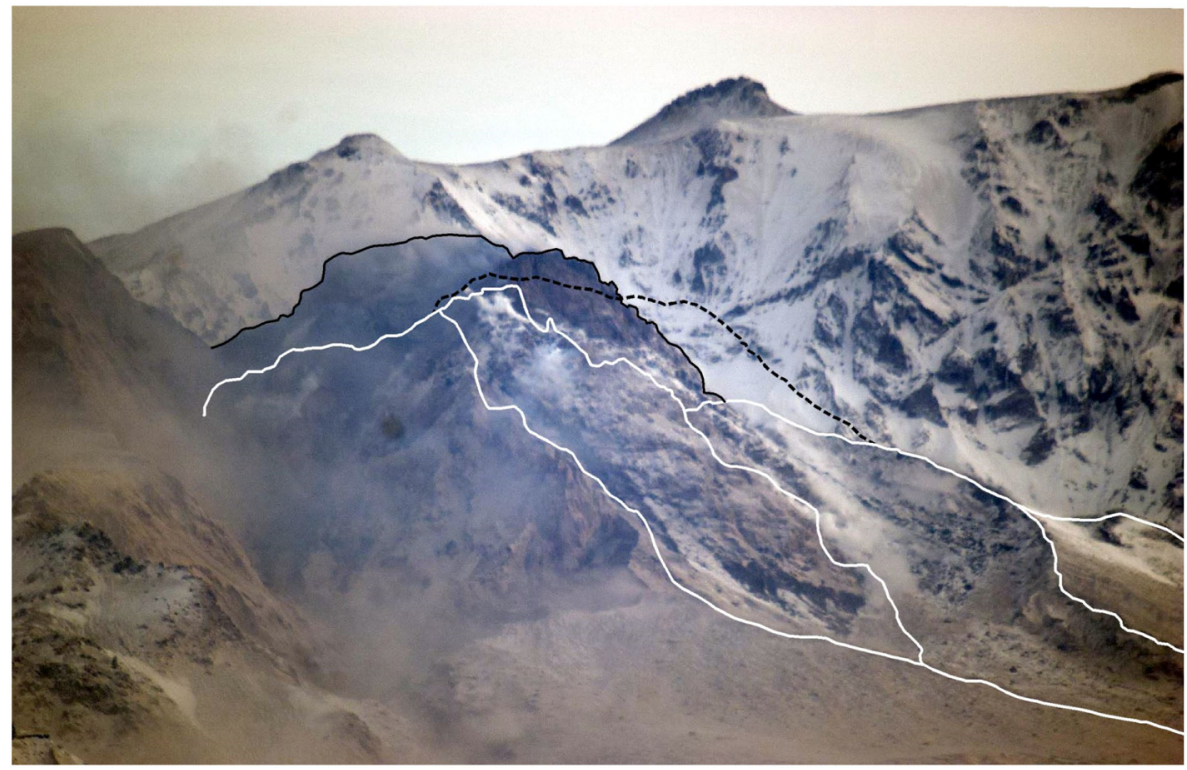

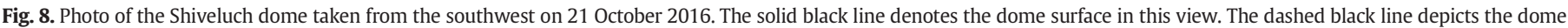

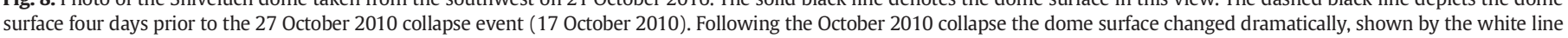

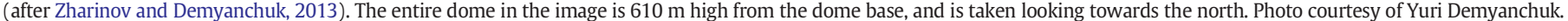


deposits that include significant channelized sections have a poor relationship between collapse area and runout distances. Similarly, the channelization of a BAF on Merapi volcano that occurred on 5 November 2010 also enhanced the runout distance from $8.4 \mathrm{~km}$ (non-confined) to 15.5 km down the Gendol River channel (Komorowski et al., 2013).

\subsection{Dome height and large collapse events}

The largest collapse events that occurred in 2005 and 2010 correspond with a maximum relative dome height (Fig. 3). The dome height ten days before the 27 February 2005 eruption was $517 \mathrm{~m}$, and the dome height prior to the 27 October 2010 eruption was $563 \mathrm{~m}$ (Zharinov and Demyanchuk, 2013). These maximum heights remained stable for over a year before the large collapse events occurred. Based on a photograph of the dome taken on 21 October 2016, the current dome height is $\sim 610 \mathrm{~m}$ (Fig. 8). The increase in height has occurred within the area of the 27 October 2010 eruption collapse scar, which has been filled with new dome material. The continued analysis of dome height and eruption data over time will show whether this is a continuing trend for the Shiveluch dome-growth and collapse cycle.

\section{Conclusions}

Shiveluch volcano has produced eight large BAFs between 2001 and 2013, including the largest dome-collapse volume and the two largest BAF deposit sizes (in terms of runout distance and deposit area) in the historic record. Using ASTER data, this study 1) investigated relationships between the dome-collapse events and the deposits that they produced, 2) described the distribution and long runout of these large BAF deposits, and 3 ) investigated the potential for correlation between areas of elevated thermal output on the dome surface to the occurrence and location of collapse events. Here, we described BAF deposits with areas that range from $3 \mathrm{~km}^{2}$ to $24 \mathrm{~km}^{2}$, and with maximum runout distances of 6.4 to $19 \mathrm{~km}$. There is direct evidence of a detached surge component for the May 2001, February 2005, and October 2010 BAFs, shown by the destruction of vegetation and the emplacement of fine-grained material surrounding the deposits. Precursory elevated thermal anomalies occur in six out of eight events with an apparent relationship between the area of elevated temperature preceding the collapse and the collapse area, especially with the 2009 failure. However, thermal precursors cannot currently be used to predict dome-collapse events as thermal anomalies occur on the dome regularly that are not followed by dome failure.

\section{Acknowledgements}

Funding for Janine Krippner was provided by the NASA, Earth and Space Science Fellowship program (NNX14AK88H) for the years 2014-17; and for Mike Ramsey by the NASA, Science of Terra and Aqua Program (NNX14AQ96G). The authors wish to thank the World Wide Lightning Location Network (http://wwlln.net), a collaboration among over 50 universities and institutions, for providing the lightning location data used in this paper. The authors would also like to thank John Pallister and Alison Graettinger for comments and discussions, and the reviewers for their efforts and insightful suggestions.

\section{References}

Andreastuti, S., Paripurno, E., Gunawan, H., Budianto, A., Syahbana, D., Pallister, J., 2017. Character of community response to volcanic crises at Sinabung and Kelud volcanoes. J. Volcanol. Geotherm. Res. https://doi.org/10.1016/j.jvolgeores.2017.01.022.

Bardintzeff, J.M., 1948. Merapi volcano (Java, Indonesia) and Merapi-Type Nuèe Ardente. Bull. Volcanol. 47 (3), 433-446.

Belousov, A.B., 1995. The Shiveluch volcanic eruption of 12 November 1964 - explosive eruption provoked by failure of the edifice. J. Volcanol. Geotherm. Res. 66, 357-365.

Belousov, A., Belousova, M., Voight, B., 1999. Multiple edifice failures, debris avalanches and associated eruptions in the Holocene history of Shiveluch volcano, Kamchatka, Russia. Bull. Volcanol. 61, 324-342.
Bernstein, M., Pavez, A., Varley, N., Whelley, P., Calder, E.S., 2013. Rhyolite lava dome growth styles at Chaitén volcano, Chile (2008-2009): interpretation of thermal imagery. Andean. Geology 40 (2), 295-309.

Bindeman, I.N., Ponomareva, V.V., Bailey, J.C., Valley, J.W., 2004. Volcanic arc of Kamchatka: a province with high-delta 0-18 magma sources and large-scale 0-18/0-16 depletion of the upper crust. Geochim. Cosmochim. Acta 68 (4), 841-865.

Bourdier, J.-L., Adburachman, E.K., 2001. Decoupling of small-volume pyroclastic flows and related hazards at Merapi volcano, Indonesia. Bull. Volcanol. 63, 309-325.

Bursik, M., Patra, A., Pitman, E.B., Nichita, C., Macias, J.L., Saucedo, R., Girina, O., 2005. Advances in studies of dense volcanic granular flows. Rep. Prog. Phys. 68, 271-301.

Calder, E.S., Lavallee, Y., Kendrick, J.E., Bernstein, M., 2015. Lava dome eruptions. In: Sigurdsson, H., Houghton, B., McNutt, S. (Eds.), The Encyclopedia of Volcanoes (2). Academic Press, Saint Louis, US, p. 2015.

Carter, A.J., Ramsey, M.S., Belousov, A.B., 2007. Detection of a new summit crater on Bezymianny Volcano lava dome: satellite and field-based thermal data. Bull. Volcanol. 69 (7), 811-815.

Charbonnier, S.J., Germa, A., Connor, C.B., Gertisser, R., Preece, K., Komorowski, J.C.-., Lavigne, F., Dixon, T., Connor, L., 2013. Evaluation of the impact of the 2010 pyroclastic density currents at Merapi volcano from high-resolution satellite imagery, field investigations and numerical simulations. J. Volcanol. Geotherm. Res. 261, 295-315.

Cole, P.D., Calder, E.S., Sparks, R.S.J., Clarke, A.B., Druitt, T.H., Young, S.R., Herd, R.A., Haford, C.L., Norton, G.E., 2002. Deposits from dome-collapse and fountain-collapse pyroclastic flows at Soufrière Hills Volcano, Montserrat. Geol. Soc. Lond. Mem. 21, 231-262.

Dirksen, O., Humphreys, M.C.S., Pletchov, P., Melnik, O., Demyanchuk, Y., Sparks, R.S.J. Mahony, S., 2006. The 2001-2004 dome-forming eruption of Shiveluch volcano, Kamchatka: observation, petrological investigation and numerical modelling J. Volcanol. Geotherm. Res. 155, 201-266.

Dvigalo, V.N., Svirid, I.Yu, Shevchenko, A.V., Sokorenko, A.V., Demyanchuk, Yu.V., 2011. Active Volcanoes of Northern Kamchatka as Seen From Aerophotogrammetric Data in 2010. Proceedings of Regional Conference "Volcanism and Associated Processes". Institute of Volcanology and Seismology FEB RAS, Petropavlovsk-Kamchatsky, pp. 26-36 (in Russian).

Fedotov, S.A., Dvigalo, V.N., Zharinov, N.A., Ivanov, V.V., Seliverstov, N.I., Khubunaya, S.A. Demyanchuk, Yu.V., Markov, I.A., Osipenko, L.G., Smelov, N.P., 2001. Eruption of Shiveluch volcano in May-July 2001. J. Volcanol. Seismol. 6, 3-15 (in Russian).

Fedotov, S.A., Zharinov, N.A., Dvigalo, V.N., Seliverstov, N.I., Khubunaya, S.A., 2004. The 2001-2004 eruptive cycle of Shiveluch Volcano. J. Volcanol. Seismol. 6, 3-14.

Fisher, R.V., Heiken, G., 1982. Mt. Pelée, Martinique: may 8 and 20, 1902, pyroclastic flows and surges. J. Volcanol. Geotherm. Res. 13 (3-4), 339-371.

Gillespie, A.R., Rokugawa, S., Matsunaga, T., Cothern, J.S., Hook, S., Kahle, A.B., 1998. A temperature and emissivity separation algorithm for advanced spaceborne thermal emission and reflection radiometer (ASTER) images. IEEE Trans. Geosci. Remote Sens. 36 (4), 1113-1126.

Girina, O.A., Senyukov, S.L., Demyunchuk, Y.V., Khubunaya, S.A., Ushakov, S.V., 2004. The eruption of Sheveluch volcano, Kamchatka, on May 10, 2004. IV International Biennial Workshop on Subduction Processes Emphasizing the Japan-Kurile-KamchatkaAleutian Arcs, Petropavlovsk-Kamchatsky.

Gorbach, N.V., 2006. Extrusive Dome Formation at Shiveluch Volcano and Its Lava Composition in 2004-2005. Proceedings of International Symposium "Problems of explosive volcanism". Institute of Volcanology and Seismology FEB RAS, PetropavlovskKamchatsky, pp. 112-119 (in Russian).

Gorbach, N.V., Portnyagin, M.V., 2011. Geology and petrology of the lava complex of young Shiveluch Volcano, Kamchatka. Petrology 19 (2), 134-166.

Gorbach, N.V., Portnyagin, M.V., Philosofova, T.M., 2016. Dynamics of extrusive dome growth and variations in chemical and mineralogical composition of young Shiveluch andesites in 2001-2013. J. Volcanol. Seismol. 10 (6), 37-61.

Gorelchik, V.I., Shirokov, V.A., Firstov, P.P., Chubarova, O.S., 1997. Shiveluch volcano: seismicity, deep structure and forecasting eruptions (Kamchatka). J. Volcanol. Geotherm. Res. 78, 121-132.

Gunawan, H., Surono, Budianto, A., Kristianto, Prambada, O., McCausland, W., Pallister, J. Iguchi, M., 2017. Overview of the eruptions of Sinabung eruption, 2010 and $2013-$ present and details of the 2013 phreatomagmatic phase. J. Volcanol. Geotherm. Res. https://doi.org/10.1016/j.jvolgeores.2017.08.005.

Gustafson, W.T., Gillespie, A.R., Yamada, G., 2006. Revisions to the ASTER temperature/ emissivity separation algorithm. In: Sobrino, J.A. (Ed.), Second Recent Advances in Quantitative Remote Sensing. Publicacions de la Universitat de València, Spain, pp. 770-775 (ISBN: 84-370-6533-X; 978-84-370-6533-5)

Hanenkamp, E. (Ed.), 2011. Decoupling Processes in Block-and-ash Flows: Field Evidence and Analogue Modelling. University of Canterbury PhD Thesis. (254 pp).

Harnett, C.E., Murphy, W., Thomas, M., Neuberg, J., 2017. Global Archive of Dome Instabilities (GLADIS). https://vhub.org/resources/4149.

Hayashi, J.N., Self, S., 1992. A comparison of pyroclastic flow and debris avalanche mobility. J. Geophys. Res. 97, 9063-9071.

Herd, R.A., Edmonds, M., Bass, V.A., 2005. Catastrophic lava dome failure at Soufrière Hills Volcano, Montserrat, 12-13 July 2003. J. Volcanol. Geotherm. Res. 148, 234-252.

Hochstaedter, A.G., Kepezhinskas, P., Defant, M., Drummond, M., Koloskov, A., 1996. Insights into the volcanic arc mantle wedge from magnesian lavas from the Kamchatka arc. J. Geophys. Res. Solid Earth Planets 101 (B1), 697-712.

Kaneko, T., Wooster, M.J., Nakada, S., 2002. Exogenous and endogenous growth of the Unzen lava dome examined by satellite infrared image analysis. J. Volcanol Geotherm. Res. 116, 151-160.

Kepezhinskas, P., McDermott, F., Defant, M.J., Hochstaedter, A., Drummond, M.S. Hawkesworth, C.J., Koloskov, A., Maury, R.C., Bellon, H., 1997. Trace element and $\mathrm{Sr}-\mathrm{Nd}-\mathrm{Pb}$ isotopic constraints on a three-component model of Kamchatka arc petrogenesis. Geochim. Cosmochim. Acta 61 (3), 577-600. 
Komorowski, J.-C., Jenkins, S., Baxter, P.J., Picquout, A., Lavigne, F., Charbonnier, S., Gertisser, R., Preece, K., Cholik, N., Budi-Santoso, A., Surono, 2013. Paroxysmal dome explosion during the Merapi 2010 eruption: processes and facies relationships of associated high-energy pyroclastic density currents. J. Volcanol. Geotherm. Res. 261, 260-294.

Major, J.M., Pierson, T.C., Hoblitt, R.P., Moreno, H., 2013. Pyroclastic density currents associated with the 2008-2009 eruption of Chaitén Volcano (Chile): Forest disturbances, deposits, and dynamics. Andean. Geology 40 (2), 324-358.

van Manen, S.M., Dehn, J., Blake, S., 2010. Satellite thermal observations of the Bezymianny lava dome 1993-2008: precursory activity, large explosions, and dome growth. J. Geophys. Res. 115, B08205. https://doi.org/10.1029/2009JB006966.

Miyabuchi, Y., 1999. Deposits associated with the 1990-1995 eruption of Unzen volcano, Japan. J. Volcanol. Geotherm. Res. 89, 139-158.

Nairn, I.A., Self, S., Cole, J.W., Leonard, G.S., Scutter, C., 2001. Distribution, stratigraphy, and history of proximal deposits from the C. AD 1305 Kaharoa eruptive episode at Tarawera Volcano, New Zealand. N. Z. J. Geol. Geophys. 44 (3), 467-484.

Nakada, S., Zaennudin, A., Yoshimoto, M., Maeno, F., Suzuki, Y., Hokanishi, N., Sasaki, H. Iguchi, M., Ohkura, T., Gunawan, H., Triastuty, H., 2017. Growth process of the lava dome/flow complex at Sinabung Volcano during 2013-2016. J. Volcanol. Geotherm. Res. https://doi.org/10.1016/j.jvolgeores.2017.06.012.

NASA LP DAAC, 2001. ASTER Level 2 Surface Radiance Product (TIR). NASA LP DAAC https://doi.org/10.5067/ASTER/AST_09T.003.

Ogburn, S.E., 2012. FlowDat: mass flow database v2.2. On Vhub at. https://vhub.org/ groups/massflowdatabase.

Ogburn, S.E., Loughlin, S.C., Calder, E.S., 2015. The association of lava dome growth with major explosive activity (VEI [greater-than or equal to] 4): DomeHaz, a global dataset. Bull. Volcanol. 77 (5), 1.

Pallister, J., Wessels, R., Griswold, J., Kartadinata, N., Gunawan, H., Budianto, A. Primulyana, S., 2017. Remote sensing of the Sinabung eruption: use of optical, IR and satellite radar imagery to monitor activity, estimate effusion rates, forecast collapse events and map the distribution of pyroclastic deposits. J. Volcanol. Geotherm. Res. https://doi.org/10.1016/j.jvolgeores.2017.06.012.

Pineau, F., Semet, M.P., Grassineau, N., Okrugin, V.M., Javoy, M., 1999. The genesis of the stable isotope $(\mathrm{O}, \mathrm{H})$ record in arc magmas: the Kamtchatka's case. Chem. Geol. 153 (1-4), 93-124.

Ramsey, M.S., Dehn, J., 2004. Spaceborne observations of the 2000 Bezymianny, Kamchatka eruption: the integration of high-resolution ASTER data into near real-time monitoring using AVHRR. J. Volcanol. Geotherm. Res. 135, 127-146.

Ramsey, M.S., Wessels, R.L., Anderson, S.W., 2012. Surface textures and dynamics of the 2005 lava dome at Shiveluch volcano, Kamchatka. GSA Bull. 124 (5/6), 678-689.

Realmuto, V.J., 1990. Separating the Effects of Temperature and Emissivity: Emissivity Spectrum Normalization. Proceedings of the 2nd TIMS Workshop 2 pp. 31-35.

Saucedo, R., Macias, J.L., Sheridan, M.F., Bursik, M.I., Komorowski, J.-C., 2005. Modeling of pyroclastic flows of Colima Volcano, Mexico: implications for hazard assessment. J. Volcanol. Geotherm. Res. 139, 103-115.

Schneider, D.J., Vallance, J.W., Wessels, R.L., Logan, M., Ramsey, M.S., 2008. Use of therma infrared imaging for monitoring renewed dome growth at Mount St. Helens, 2004. In: Sherrod, D.R., Scott, W.E., Stauffer, P.H. (Eds.), A Volcano Rekindled: The Renewed Eruption of Mount St. Helens, 2004-2006. 1750. U.S. Geological Survey Professional Paper, pp. 347-360.

Shevchenko, A.V., Svirid, I. Yu, 2014. Collapsing Processes of the Current Lava Dome at Molodoy Shiveluch Volcano. Proceedings of the XIII Regional Youth Conference "The Natural Environment of Kamchatka". Institute of Volcanology and Seismology FEB RAS, Petropavlovsk-Kamchatsky, pp. 129-142 (in Russian).

Shevchenko, A.V., Dvigalo, V.N., Svirid, I.Y., 2015. Airborne photogrammetry and geomorphological analysis of the 2001-2012 exogenous dome growth at Molodoy Shiveluch Volcano, Kamchatka. J. Volcanol. Geotherm. Res. 304, 94-107.

Solikhin, A., Pinel, V., Vandemeulebrouck, J., Thouret, J.-C., Hendrasto, M., 2015. Mapping the 2010 Merapi pyroclastic deposits using dual-polarization synthetic aperture radar (SAR) data. Remote Sens. Environ. 158, 180-192.
Sparks, R.S.J., Barclay, J., Calder, E.S., Herd, R.A., Komorowski, J.-C., Luckett, R., Norton, G.E., Ritchie, L.J., Voight, B., Woods, A.W., 2002. Generation of a debris avalanche and violent pyroclastic density current on 26 December (Boxing Day) 1997 at Soufrière Hills Volcano, Montserrat. In: Druitt, T.H., Kokelaar, R. (Eds.), The Eruption of Soufrière Hills Volcano, Montserrat from 1995 to 1999. 21. Geological Society Memoirs, pp. 409-434.

Surono, Jousset, P., Pallister, J., Boichu, M., Fabrizia Buongiorno, M., Budisantoso, A., Costa, F., Andreastuti, S., Prata, F., Schneider, D., Clarisse, L., Humaida, H., Sumarti, S., Bignami, C., Griswold, J., Carn, S., Oppenheimer, C., Lavigne, F., 2012. The 2010 explosive eruption of Java's Merapi volcano-a ‘100-year' event. J. Volcanol. Geotherm. Res. 241-242, 121-135.

Tadahide, U., Matsuwo, N., Sumita, M., Fujinawa, A., 1999. Generation of block and ash flows during the 1990-1995 eruption of Unzen Volcano, Japan. J. Volcanol. Geotherm. Res. 89, 123-137.

Thouret, J.-C., Gupta, A., Lube, G., Liew, S.C., Cronin, S.J., Surono, 2010. The 2006 pyroclastic deposits of Merapi Volcano, Java, Indonesia: high-spatial resolution IKONOS images and complementary ground based observations. Remote Sens. Environ. 144 (9), 1949-1967.

Thouret, J.-C., Kassouk, Z., Gupta, A., Liew, S.C., Solikhin, A., 2015. Tracing the evolution of 2010 Merapi volcanic deposits (Indonesia) based on object-oriented classification and analysis of multi-temporal, very high resolution images. Remote Sens. Environ. $170,350-371$.

Tolstykh, M.L., Naumov, V.B., Babanskii, A.D., Khubunaya, S.A., Kononkova, N.N., 2000. Chemical composition, trace elements, and volatile components of melt inclusions in minerals from andesites of the Shiveluch volcano, Kamchatka. Geochem. Int. 38, 123-132.

Tonooka, H., Palluconi, F.D., 2005. Validation of ASTER/TIR standard atmospheric correction using water surfaces. IEEE Trans. Geosci. Remote Sens. 43, 2769-2777.

Urai, M., Fukui, K., Yamaguchi, Y., Pieri, D.C., 1999. Volcano observation potential and global volcano monitoring plan with ASTER. Bull. Volc. Soc. Japan 11 (16), 131-141.

Vallance, J.W., Bull, K.F., Coombs, M.L., Power, J.A., Coombs, M.L., Freymueller, J.T., 2010. Pyroclastic Flows, Lahars, and Mixed Avalanches Generated During the 2006 Eruption of Augustine Volcano, The 2006 Eruption of Augustine Volcano, Alaska. US Geological Survey, Professional Papers, 2010 Vol. 1769 pp. 219-268.

Vaughan, R.G., Hook, S.J., Ramsey, M.S., Realmuto, V.J., Schneider, D.J., 2005. Monitoring eruptive activity at Mount St. Helens with TIR image data. Geophys. Res. Lett. 32. https://doi.org/10.1029/2005GL024112.

VONA/KVERT Weekly Release, d. KVERT, Institute of Volcanology and Seismology FEB RAShttp://www.kscnet.ru/ivs/kvert/van/index.php?type=3.

Wadge, G., Voight, B., Sparks, R.S.J., Cole, P.D., Loughlin, S.C., Robertson, R.E.A., 2014. An overview of the eruption of Soufrière Hills Volcano, Montserrat from 2000 to 2010. In: Wadge, G., Robertson, R.E.A., Voight, B. (Eds.), The Eruption of Soufriere Hills Volcano, Montserrat from 2000 to 2010. 39. Geological Society, London, Memoirs: pp. 1-39. https://doi.org/10.1144/M39.1.

Wessels, R.L., Vaughan, R.G., Patrick, M.R., Coombs, M.L., 2013. High-resolution satellite and airborne thermal infrared imaging of precursory unrest and 2009 eruption at Redoubt Volcano, Alaska. J. Volcanol. Geotherm. Res. 259, 248-269.

Yulianto, F., Suwarsono, Sofan, P., 2016. The utilization of remotely sensed data to analyze the estimated volume of pyroclastic deposits and morphological changes caused by the 2010-2015 eruption of Sinabung Volcano, North Sumatra, Indonesia. Pure Appl. Geophys. 173, 2711-2725.

Zharinov, N.A., Demyanchuk, Y.V., 2008. The growth of an extrusive dome on Shiveluch Volcano, Kamchatka in 1980-2007: geodetic observations and video surveys. J. Volcanol. Seismol. 2 (4), 217-227.

Zharinov, N.A., Demyanchuk, Y.V., 2013. Large Explosive Eruptions of Shiveluch Volcano, Kamchatka Resulting in Partial Destruction of the Extrusive Dome (February 28, 2005 and October 27, 2010). 